Influence of Riparian Tree Phenology on Lower Colorado River Spring-Migrating Birds: Implications of Flower Cueing

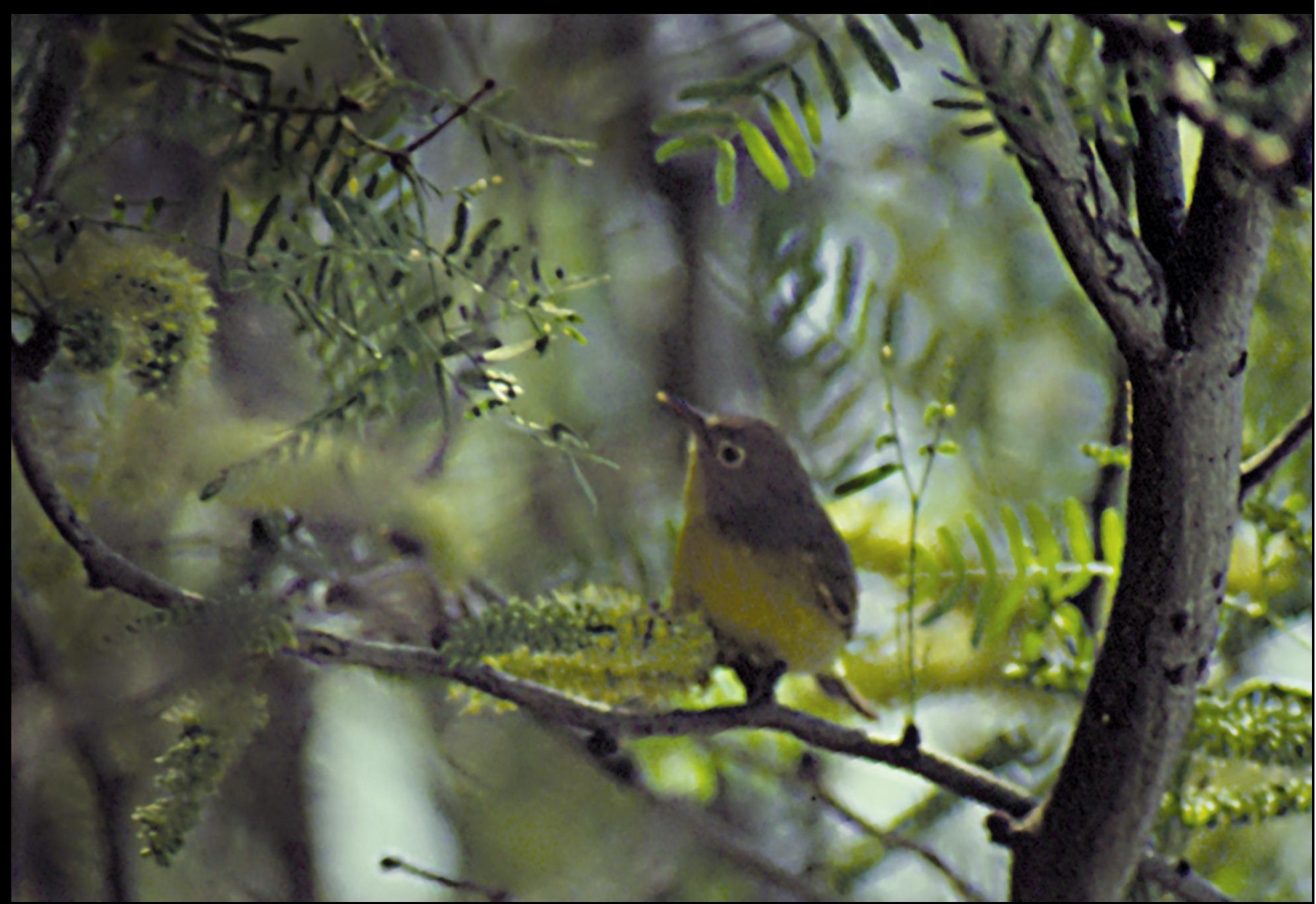

Southwest Biological Science Center

Open-File Report 2005-1140

April 2005

U.S. Department of the Interior

U.S. Geological Survey 


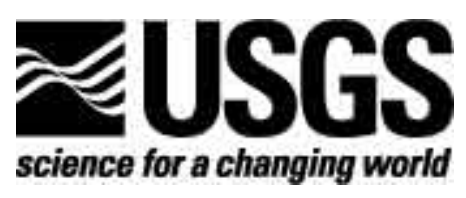

In cooperation with Northern Arizona University, Department of Biological Sciences

\section{Influence of Riparian Tree Phenology on Lower Colorado River Spring-Migrating Birds: Implications of Flower Cueing}

By Laura J. McGrath and Charles van Riper III

Open-File Report 2005-1140

April 2005 


\section{U.S. Department of the Interior \\ Gale A. Norton, Secretary}

\section{U.S. Geological Survey \\ Charles G. Groat, Director}

U.S. Geological Survey, Reston, Virginia: 2005

Note: This document contains information of a preliminary nature and was prepared primarily for internal use in the U.S. Geological Survey. This information is NOT intended for use in open literature prior to publication by the investigators named unless permission is obtained in writing from the investigators named and from the Station Leader.

\section{Suggested Citation}

McGrath, L. J., and C. van Riper III. 2005. Influence of Riparian Tree Phenology on Lower Colorado River Spring-Migrating Birds: Implications of Flower Cueing. USGS Open-File Report 2005-1140. U.S. Geological Survey, Southwest Biological Science Center, Sonoran Desert Research Station, University of Arizona, Tucson, AZ.

Cover photo: Kristina Ecton, Nashville Warbler 


\section{Authors}

Laura J. McGrath

Department of Biological Sciences

USGS SBSC Colorado Plateau Research Station

PO Box 5614

Northern Arizona University

Flagstaff, AZ 86011
Charles van Riper III

USGS SBSC Sonoran Desert Research Station

125 Biological Sciences East

University of Arizona

Tucson, AZ 86521

\section{U.S. Geological Survey Station Personnel}

Charles van Riper, III, Station Leader

Steve P. Gloss, Ecologist

William L. Halvorson, Research Ecologist

Cecil R. Schwalbe, Ecologist

Michael R. Kunzmann, Ecologist

\section{Program and Expertise Areas of USGS and UA Personnel}

Administration \& Outreach

Cori Dolan

Wendy Parrish

Charles van Riper, III

Avian Ecology

Claire Crow

Glenn Johnson

Mike Kunzmann

Chris O'Brien

Brian Powell

Charles van Riper, III

Data Management

Mike Kunzmann

Brent Sigafus

Ecology of Amphibians \& Reptiles

Kevin Baker

Cristina Jones

Dave Prival

Phil Rosen

Cecil Schwalbe

Brent Sigafus

Eric Stitt

Dennis Suhre
Fire Management

Cori Dolan

James Feldmann

Bill Halvorson

Invasive Species Research

Patricia Guertin

Jim Malusa

Phil Rosen

Cecil Schwalbe

Brent Sigafus

Dennis Suhre

Inventory \& Monitoring

Patricia Guertin

Bill Halvorson

Brian Powell

Cecilia Schmidt

Vegetation Mapping \& Ecology

Patricia Guertin

Bill Halvorson

Jim Malusa

USGS Southwest Biological Science Center http://sbsc.wr.usgs.gov 


\section{Table of Contents}

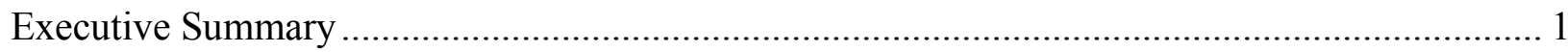

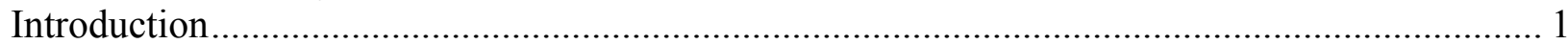

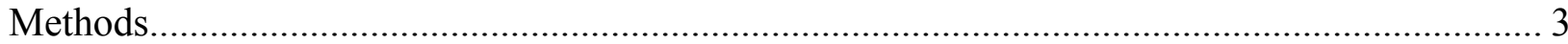







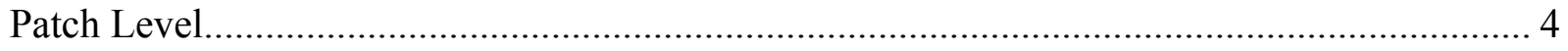

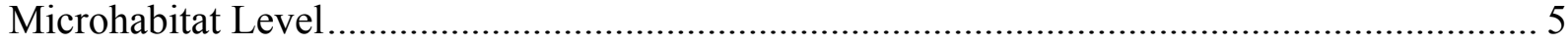

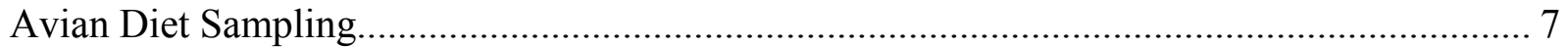

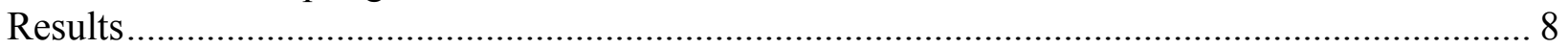

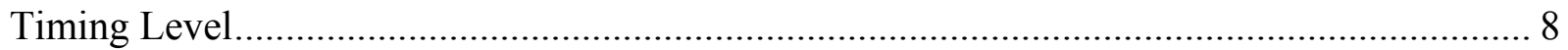

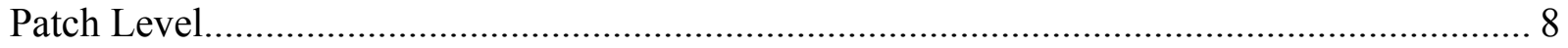

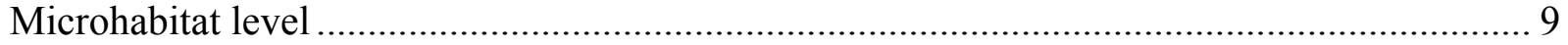

Avian Foraging Behavior at Paired Flowering Levels ………................................................ 9

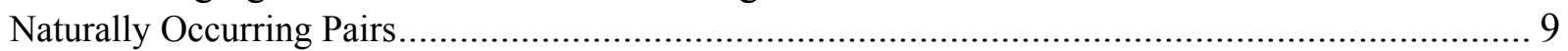



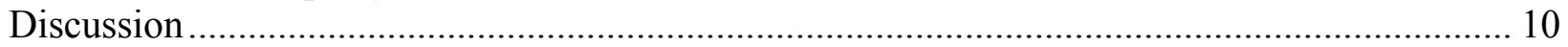

Timing Level: Migrant Arrivals Associated with Tree Phenology ………………………..... 10

Patch level: Habitat Decisions Associated with Tree Phenology …………………………..... 11

Microhabitat level: Habitat Decisions Associated with Tree Phenology ................................. 12

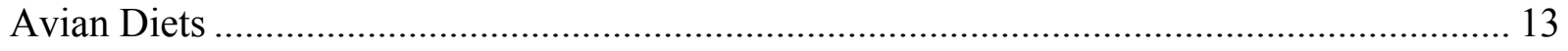

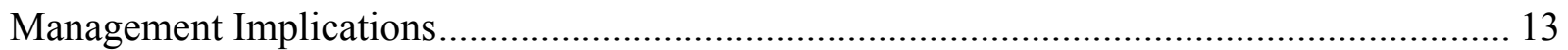

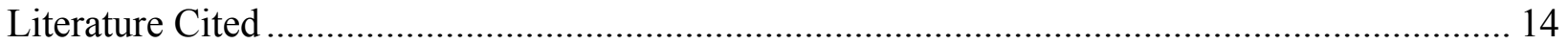

\section{List of Tables}

Table 1. Migratory birds assigned to the leaf-gleaning insectivorous guild that used Cibola NWR, Arizona as stopover habitat during spring migration 2002 and 2003 ...................... 18

Table 2. Pearson's Correlations for phenology of the dominant riparian tree species by the

relative abundance of migrants. ……………………......................................................... 19

Table 3. Based on first attack maneuvers; A) Relative heights of bird foraging locations among all tree species * B) Relative heights of bird foraging locations in honey mesquite............ 20

Table 4. Chi-Square values comparing the proportion of arthropods found in diets versus available arthropods by order and by morpho-species* level of identification..................... 21

Table 5. Chi-square values comparing the proportion of prey items identified to morpho-species



Table 6. Arthropods found in the diets of the three representative insectivores........................... 23

\section{List of Figures}

Figure 1. Relative insectivorous migrant abundance during honey mesquite flowering throughout Spring migration at Cibola NWR in Arizona...........................................25

Figure 2. Arthropod sampling from Fremont Cottonwood (CO), Honey mesquite (HM), Screwbean mesquite (SM) and Goodding's willow (WI) in 2003 at Cibola NWR in

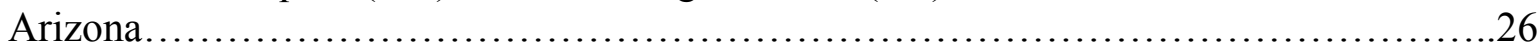


Figure 3. Proportion of substrate use by migrant birds for 2002 and 2003 at Cibola NWR in

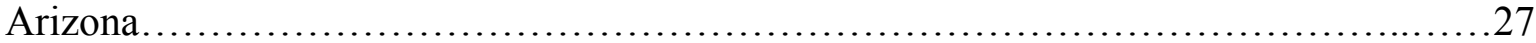

Figure 4. Panel (A) flowering affects arthropod abundance. Panel (B) flowering affects

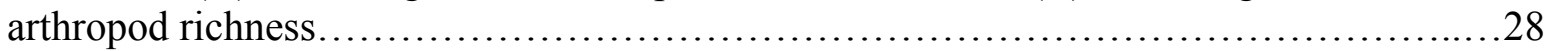

Figure 5. Arthropod abundance increases as flowering level increases. ................................ 29 Figure 6. 2002 and 2003 mean flower levels (honey Mesquite) used by migrants compared with mean flower availability at the site.............................................. 30

Figure 7. Natural Pairs are simultaneous tree observations of birds at heavy and light flowering levels $(\mathrm{n}=49)$

Figure 8. Natural Pairs are simultaneous tree observations of birds at heavy and light flowering leveles $(n=49)$

Figure 9. Proportion of items identified to order found in the diets of the three representative insectivores (Nashville, Orange-crowned, and Wilson's warblers).

Figure 10. Proportion of items identified to morpho-species (morphologically distinct taxa) found in the diets of the representative insectivores (Nashville, Orange-crowned, and Wilson's Warblers).

Figure 11. Proportion of insects significantly affiliated with the flowering condition found in the diets of the three representative insectivores (Nashville, Orange-crowned, and Wilson's Warblers)

\section{Acknowledgements}

Any scientific work is never a single effort, but a direct result of assistance by many individuals. We thank Thomas Whitham and Carol L. Chambers who unselfishly devoted their time and effort to improving this study. We would also like to thank Kristina Ecton and Chris O'Brien who contributed assistance in the field and whose ideas on migratory birds are reflected throughout much of this study. Discussions with Frank Moore from Mississippi State U. on bird migration, and Earl Andrus of USDA APHIS and Neil Cobb from Northern Arizona University on identification of bug fragments, greatly assisted us with defining the parameters of this study.

The Cibola NWR provided much needed logistical support throughout this study, and we would especially like to thank Brenda Zaun and Mike Hawks who understood the importance of Cibola as a stop-over site for migratory birds. Douglas Buffington and Dennis B. Fenn provided encouragement and/or financial assistance from the USGS for this study. Additional financial support was provided by the National Fish and Wildlife Foundation, and Budweiser Conservation Scholarship Program.

The dedicated people of the USGS Colorado Plateau Research Station (Mark Sogge, R. Stevens, C. Drost, David J. Mattson, Matt Johnson) and Northern Arizona University (Tad Theimer, Mike Kearsley, Kristen Covert, Lee Ann Compton, Scott Durst, Suzanne Cardinal, Jeff Gagnon and Shirley Bartz), provided much needed support and assistance throughout this study. Rebecca Cameron helped with collecting field information and Marlyse Waskiewicz with arthropod identifications. Finally, we express deep appreciation to Christopher Geanious and Sandra Guest van Riper for their support and understanding during the time that this study was in progress. 


\section{Executive Summary}

Neotropical migrant birds make choices about which habitats are most likely to provide successful foraging locations during migration, but little is known about how these birds recognize and process environmental clues that indicate the presence of prey species. Aspects of tree phenology, notably flowering of trees along the lower Colorado River corridor, coincide with the migratory stopovers of leaf-gleaning insectivorous songbirds and may be an important indicator of arthropod prey species availability.

Shifting tree flowering and leaf flush during the spring migration period presents avian insectivores with an assortment of foraging opportunities. During two field seasons at Cibola National Wildlife Refuge in southwestern Arizona, we examined riparian tree species to test whether leaf-gleaning insectivorous birds are attracted to the flowering condition of trees in choosing foraging sites. We predicted that flowering trees would host more insect prey resources, would thus show increased visit rates, length of stays and attack ratios of migrant avian insectivores, and that those arthropods would be found in the stomach contents of the birds. Paired trees of honey mesquite (Prosopis glandulosa), displaying heavy and light degrees of flowering were observed to test these predictions. To test whether birds are tracking arthropods directly or are using flowers as a proximate cue, we removed flowers from selected trees and paired these treated trees with neighboring high flowering trees, which served as controls. Avian foraging behavior, avian diets, arthropods, and phenology data were collected at the same time to control for temporal differences in insect availability, plant phenology, and differences in stopover arrivals of birds.

We documented five patterns from this study: 1) Higher abundance and richness of arthropods were found on honey mesquite trees with greater numbers of flowers. 2) Arthropod abundance and richness increased as flowering level increased.

3) The subset of migrant avian insectivores selected for study disproportionately foraged among honey mesquite trees with significantly greater amounts of flower coverage than they did on trees with less than average flower coverage.
4) Paired field experiments demonstrated that migrant avian insectivores more often visited, stayed longer, and had higher attack rates on insect prey in honey mesquite trees with greater numbers of flowers. 5) Diet analyses of selected avian insectivores showed over half of their diet consisted of prey significantly associated with honey mesquite flowering. Combined, these results suggest that honey mesquite flowering condition is an important cue used by avian insectivores that enables birds to quickly find arthropod prey at stop-over locations, while in transit during spring migration.

\section{Introduction}

Neotropical insectivorous songbirds face physiologically demanding challenges during spring migration between wintering and breeding grounds. The most critical is their need to find food quickly in unfamiliar habitats (Moore et al. 1993). Predation (Connell 1975), constraints on foraging, (Noon 1981, Weins 1983, Sherry and Holmes 1988), patchy food distribution (Pyke et al. 1977), and food availability (Hilden 1965, Root 1967, van Riper 1984, Morris et al. 1958) all affect the distribution of migrating bird communities in time and space.

Food availability is likely the single most important factor in habitat selection for migrating birds (Hutto 1985a). Because migration routes can span large distances (Rappole 1995), food resources between wintering and breeding grounds vary enormously and may be altogether novel for birds in transit. During spring migration, there is strong selective pressure to minimize time spent migrating and to arrive quickly at breeding sites to successfully compete for optimal breeding territories (Linderstrom 1995). Given these constraints during the energetically stressful time of migration, birds should demonstrate efficiency in how they expend energy and locate food quickly. Constraints such as these led Moore and Aborn (2000) to argue "energetically-constrained migrants should focus on structural features as cues when selecting habitat during stopover."

These structural cues have been modeled as a hierarchy in habitat selection for breeding (Johnson 1980), and for migrating birds (Hutto 
1985a, Moore et al. 1995). Johnson (1980) modeled four orders of breeding habitat selection; (1) geographical range selection, (2) home range within geographic range, (3) patch choice within the home range, and (4) microhabitat selection where food is procured. Hutto (1985a) modeled three levels of migration decision-making: (1) innate or migratory path-type decisions, (2) landscape features, and (3) microhabitat use within a stand where food is procured. We incorporated aspects of both models, formulating a site-specific 4-level decision model and adapting that to ask questions relevant to our study.

The first factor of any migration foraging model has to be the timing of arrivals at stopover sites (migratory rest stops). There may be innate aspects of site arrival times (Hutto 1985a), but there is increasing evidence for additional factors including depleted energy reserves (Moore and Simmons 1992), site fidelity (Merom et al. 2000), and grounding due to inclement weather (Moore and Aborn 2000). We also believe that latitudinal advances of spring plant phenology patterns (e.g., leaf flush and bloom) influence stopover timing.

Once a migrating bird decides to descend, there appear to be four scales of decision-making. The first choice is quite broad, what coarse landscape feature to target. For example, the choice of riparian versus upland-shrub, versus grassland habitats. When approaching that landscape feature, the next three model levels deal with more specific habitat decisions, from the patch (e.g., what group of trees, shrubs or grassland), to which specific portion of the patch (e.g., what specific tree, shrub, or grass clump) and finally to the microhabitat scale (e.g., what location within the tree, shrub, or grass).

What happens when a bird in migration is confronted with a storm front and is forced to descend? The first level of decision might be to target a ribbon of riparian trees in a "sea" of desert. The second decision would be made during its flight over the ribbon of riparian corridor, when the bird selects a patch of trees. Within that patch, the bird then selects a particular plant species based on its structure, phenology, or some other cue indicating potential availability of prey. Finally, after landing in the chosen tree, the bird makes decisions specifically where to procure food within that foraging substrate. This hierarchical selection process focuses on decisions a migrating bird makes to acquire food, but excludes other possible decisions impacting a settling response (as defined by Hildén 1965) such as predation or competition from resident and other conspecific birds.

Stopover habitat use by migrating songbirds is non-random because food sources are nonrandomly distributed (Moore et al. 1995, Skagen et al. 1998). These non-random opportunities form the basis of habitat selection, and those decisions should impact the success of an individual bird's migration and subsequent fitness (Rice et al. 1980, Klopfer and Ganzhorn 1985, Moore et al. 1995, Lynn and Averill 1996, Hutto 1998).

Mechanisms that birds use to evaluate relative food availability among stopover habitats are not well understood, but are probably scale dependent (Hutto 1985b, Block and Brennan 1993, Moore and Aborn 2000). Studies on microhabitat selection report that birds cue on structural features that correlate with food availability or hunting technique such as needle architecture (Parrish 2000), leaf-types (Greenberg 1985), and leaf dispersion (Whelan 2001). Migrant avian insectivores make numerous habitat choices during migration (Moore et al. 1995), but little is known about the influence of tree phenology on stopover foraging behavior.

Latitudinally shifting tree phenology (especially flowering and leaf-flush) during spring migration may present insectivorous migrant birds with cues that maximizes their chances of settling into a patch (or a microhabitat) with abundant insect resources. Marques et al. (2000) found that woody fabaceous desert trees offering more abundant leaves and flowers had greater insect species richness and abundance. This association between flowering plants and insects led us to ask the fundamental question: If flowering plants attract insects, do they also attract the birds that feed on those insects? If the flowering condition increases richness and abundance of insect prey resources, then would insectivorous migrant birds incorporate a searching strategy that includes flowering as one cue during spring migration?

We hypothesized that phenological cues presented by dominant riparian tree species, especially flowering, would be recognized by birds and 
would influence where they forage. We tested whether the flowering condition might act as a cue by incorporating multiple lines of evidence (avian numbers, foraging behavior, arthropod sampling, and avian stomach sampling), at two habitat-level scales (patch and microhabitat). We asked: (1) Does the timing of spring migration correlate with phenology patterns of dominant riparian trees? (2) At the patch level we explored the proportion of migrant use of dominant riparian trees species, and because the abundance of insects may directly influence bird presence, which tree hosts the most abundant and rich insect resources? (3) At the microhabitat level we asked, (a) Are migrant foraging decisions influenced by a tree's phenologic stage (e.g., level of flowering and leafing)? (b) Do migrants attack more prey, stay longer, and visit more frequently those trees with high degrees of flowering? And, (c) are richness and abundance of arthropod species influenced by a tree's phenological stage (heavy versus light flowering)? (4) Finally, we address the question: Do birds select prey in proportion to availability and according to tree species and phenology associated with that prey?

There is a paucity of research on western migration in general (but see Skagen et al. 1998, Finch and Yong 2000, Kelley et al. 2002), and there have been no previous studies within the southwestern United States that associate seasonal plant phenology with migrant songbird food availability. The lack of understanding of this association may be especially important because of the continuing decline of riparian habitat in the Southwest. In the last century riparian habitat has been lost or degraded because of agricultural clearing, the introduction of the exotic tamarisk tree (Tamarix sp.) and water management practices that have hindered native plant regeneration (Rosenberg et al.1991). Declines of western migratory birds associated with these stopover habitats have been reported (Finch and Yong 2000). Even so, riparian corridors support 10 times the number of Neotropical birds per hectare than adjacent non-riparian upland habitats (Stevens et al. 1977, Wauer 1977). The lower Colorado River is bordered by hundreds of square kilometers of dry, harsh, mountainous expanses of Sonoran and Mohave Desert, making riparian stopover habitat in this southwestern flyway even more important to refueling migrating birds.

\section{Methods}

\section{Study Area}

This research was undertaken in the arid southwestern United States on the lower Colorado River corridor at Cibola National Wildlife Refuge (NWR). Annual precipitation averages less than 6 $\mathrm{cm}$. The site consists of 32 hectares that was revegetated in 1991 to restore riparian woodland habitat after channelization of the Colorado River. Plantings were orchard-style, with saplings placed in rows to facilitate drip irrigation (Rosenberg et al. 1991). Based on canopy cover of tree species, the site consists of 40 percent Fremont cottonwood (Populous fremontii), 25 percent honey mesquite (Prosopis glandulosa), 17 percent screwbean mesquite (Prosopis pubescens), and 7 percent Goodding's willow (Salix gooddingii). Almost all of the trees are even aged, and mature. Exotic tamarisk (Tamarix sp.) comprises 11 percent of the habitat and has only recently invaded this site but is a dominant landscape feature in the adjacent riparian corridor. Common shrubs include arrow weed (Tessaria sericea), quailbush (Artiplex lentiformis), wolfberry (Lycium sp.), and baccharis (Baccharis sp.). This re-vegetation site is ideal to test questions regarding patch and microhabitat selection because tree species are clustered yet heterogeneously dispersed. Data were collected during the spring migration period, between mid March and early May for 2002 and 2003.

\section{Focal Avian Species}

We focused our efforts on three species in the avian leaf-gleaning insectivorous guild to answer questions regarding foraging behavior and relationships with tree phenology: Nashville warbler (Vermivora ruficapilla), Orange-crowned warbler (Vermivora celata), and Wilson's warbler (Wilsonia pusilla). These species are the most abundant migrants at Cibola NWR during spring. All three warblers are considered through migrants, as they do not over winter or breed at that location (Rosenberg et al. 1991, Rappole 2000). Warblers make up 52.4 percent of the Neotropical through migrants stopping over in terms of numbers of individuals and 24 percent of the species (Rosenberg et al. 1991, van Riper unpublished data). Eleven other species of 
migrants in the leaf-gleaning insectivorous guild were also selected for testing (Table 1). These birds span three families in the order Passeriformes and serve to test foraging patterns across a greater community and species composition. The latter species were pooled during analyses and termed "other" birds. All statistical tests were run on the program SPSS version 10 (SPSS Inc. 2001). Probability values of 0.05 or less were considered statistically significant.

\section{Timing Level}

\section{Tree Phenology to Determine Habitat Availability}

We collected site-level phenology data on the five dominant riparian tree species to determine availability of the stands' leaf and flower coverage. Availability is defined as leaf and flower coverage accessible to migrants during stopover at Cibola NWR (as defined by Johnson 1980). A total of 100 trees of each of the five species were visually sampled weekly for phenology patterns (after van Riper 1980) by the same observer. An individual tree was assessed by visually estimating what percentage was in leaf, flower, and fruit coverage. We refer to the percentage of leaf or flower, and fruit cover estimated from each tree as "level." Data from 100 trees of each species were averaged to obtain weekly stand conditions for the five tree species. Reference photographs for our microhabitat tree focal species, honey mesquite, were taken to compare flower and leaf levels of field estimations with photo estimations to determine accuracy of our visual estimations. Photo distance was standardized. A field estimation of the percent leaf and flower of each tree was made at the time each reference photograph was taken. Photos were overlaid with a grid divided into onecentimeter squares and then 100 squares were counted for leaf and flower cover. We could not detect a difference between field estimations of flower and leaf cover and photo estimations, demonstrating that our method produced consistent phenology estimations in the field $(\mathrm{t}=$ $14.38, \mathrm{p}=0.17)$.

\section{Avian Surveys}

We conducted point counts using the variable circular plot method (Reynolds et al.1980) at eight points weekly throughout the entire spring migration period. Surveys commenced at sunrise and ended by 0900 hours during active migrant vocalization periods. Tree phenology sampling and avian surveys were taken simultaneously for a total of 16 replications in 2002 and 2003. Because migrant species arrival patterns are consistent from year to year (Rosenberg et al. 1991, van Riper unpubl. data), and the timing of leafing and flowering is also relatively consistent, we were able to pool data from 2002 and 2003. Bird survey data were compared with tree stand phenology data to compare numbers of spring migrant birds with tree leaf-flush and flowering patterns. Pearson's Correlations for leaf and flower level against migrant numbers were determined for each tree species.

\section{Patch Level}

\section{Arthropod Sampling}

To obtain an overall representation of arthropod abundance from the five dominant riparian tree species, we sampled insects twice during peak spring migration in 2003 (4/18 and 5/06). First attack maneuvers from 661 migrant birds were analyzed from three spring periods (2001-2003) to determine "attack zones" on tree species where arthropod sampling should occur in effort to be consistent with migrant bird foraging activity. We defined attack maneuvers as behavior where the bird is in pursuit of prey (e.g., eat, glean, hammer, probe).

Branch-bagged samples were collected at the "attack zone" to sample foliage-dwelling insects during peak migration. This technique captures active and inactive insects likely to be hunted by the predominantly leaf-gleaning insectivores in this study (after Johnson 2000). One branch sample was collected per tree. The branch was shaken into a sweep net, and insects collected from the net and transferred into 1-gallon ziplock bags. We controlled for foliage surface area by choosing branches with similar stem diameter. Samples were frozen immediately and brought to the laboratory for processing. From each sample, arthropods were sorted, counted, and identified. 
Voucher specimens from samples were mounted and placed in a reference collection. The remaining insects were stored by sample in 70 percent ethanol.

Arthropods were identified to the lowest taxonomic level possible (Borror et al. 1989). Morphologically distinct taxa were considered to be unique species, and were categorized as morpho-species. This level of identification was important because it enabled us to link an insect fragment found in a bird's stomach (described later) to the tree species where the insect most often occurred and to the phenological condition (e.g., leafing and flowering) it was most associated with in effort to illuminate a mechanism to which the birds may be responding.

A One-way Anova with Games-Howell Post Hoc tests (Games and Howell 1976) was used to test differences in mean richness and abundance of arthropods among tree species.

\section{Random Sampling of Avian Foraging Behavior}

To determine foraging patches used by migrant insectivores, we compared the proportion of use of the five trees species. All leaf-gleaning insectivorous migrants that performed an attack maneuver were included in our analyses (Table 1). "Use" is defined as the proportion of "first attack maneuvers" each of the migrants performed while foraging on a particular tree species. For all foraging behavior analyses we used only attack maneuvers. Attack maneuver data were used for three reasons, (1) these maneuvers specifically address foraging locations (as opposed to singing, perching, and searching sites), (2) they serve as independent observations as only the first attack maneuver in an observation was used (Bell et al. 1990), and (3) their use reduces visual bias differences in foraging behavior between tree species, (e.g., conspicuous versus inconspicuous foraging locations; Sturman 1968, Hertz et al. 1976, Bradley 1985).

Random foraging observations were collected along the same transect used to collect phenology and avian survey data. The transect intersected all dominant tree types but similar foraging observation effort was given to each tree type (in hours) so that all tree species were observed equally. In order to avoid replicating observations on individual birds, each transect was walked only once per day and foraging observations were collected with a minimum of two days between efforts. Repeated sampling of the same individual should be rare because most Neotropical migrants depart the night following their arrival (Gauthreaux 1971, 1972, Moore and Kerlinger 1987, Kuenzi et al. 1991), and we found that spring migrant birds rarely remain more than two days at Cibola (pers. obs.).

To compare availability versus use for each foraging bout, the phenology of the tree that the bird foraged in (leaf and flower level) was recorded and then compared to the mean site phenology level. A hand-held tape recorder was used to collect foraging behaviors for each bout and then transcribed to data sheets. We measured "available" vegetation using weekly stand phenology estimations (described earlier) from each of the five dominant tree species at the site (after Reynolds et al. 1980). For example, a bird foraged in a honey mesquite tree that was 40 percent in flower, yet the stand average for honey mesquite in flower that week was only 30 percent. The resulting difference was a bird choosing a foraging tree 10 percent above the average stand condition.

Chi Square Likelihood Ratio tests with Bonferroni adjustments were performed to test differences between the proportion of a particular tree species leaf and flower percentage used by migrants versus the average stand condition of leaf and flower percentage for that particular tree species (Zarr 1999, p. 461, Neter et al. 1996, p.736).

\section{Microhabitat Level}

\section{Arthropod Sampling}

We branch sampled arthropods from heavy and light flowering honey mesquite trees. Because varying levels of honey mesquite flowering occur simultaneously throughout much of spring migration, it is ideal for testing differences in arthropod distributions based on phenology. We sampled arthropods twice in 2002 and three times in 2003 to examine arthropod abundance and richness patterns associated with heavy and light flowering conditions. One branch sample per tree was collected on either a heavy or light flowering honey mesquite tree in the morning during active 
avian foraging time. Arthropods were processed as described in patch-level arthropod sampling.

Computing the average stand flower level for the week, and then adding or subtracting 20 percent to that value determined assignment of heavy and light flower levels. For example, if the weekly flower level for the stand was 40 percent then a heavy flowering tree had to be 20 percent over the average $(60 \%$ or $>)$, similarly, light flowering trees were selected 20 percent below the average stand level $(20 \%$ or $<)$. A single observer recorded stand-level flower and leaf percentages throughout the season to control for observer differences. To standardize phenology level estimations from 2002 to 2003, sample photos were used as guides for estimations.

Using branch-bagged samples, two analyses were performed to determine arthropod assemblage differences at the microhabitat level. First, a Student's t-test (SPSS Inc. 2001) was used to compare mean differences in arthropod abundance and richness between heavy and light flowering levels. All tests were performed at the lowest taxonomic identification (e.g., morpho-species). Because there were significant differences between and within years among sample sessions, data are represented by individual and yearly sampling sessions.

Second, arthropod abundance and richness was regressed against a flowering level continuum to determine if arthropods increase along a flowering gradient. Data were natural log transformed to meet normality assumptions.

\section{Random Sampling of Avian Foraging Behavior}

Honey mesquite trees were used to identify foraging patterns associated with phenology at the microhabitat level. Average site leaf and flower levels were sampled visually as described above. Each tree used by a migrant was similarly sampled for leaf and flower level.

Non-parametric Wilcoxon Signed Rank paired Z tests (Wilcoxon 1945) were used to determined if the flower and leaf levels of individual trees used by each of the three focal warbler species were different from the site average leaf and flower levels. Furthermore, to explore whether other leafgleaning insectivorous migrants showed similar patterns of use, phenology selections made by eleven "other" migrant species were similarly pooled and tested. Year-to-year foraging behaviors differed, therefore, 2002 and 2003 data are presented independently.

\section{Avian Foraging Behavior at Paired Flowering Levels}

We observed migrants at tree pairs displaying heavy and light flowering levels to perform additional microhabitat investigations on tree phenology selection by leaf-gleaning insectivores. Trees comprising a pair were located within 10 meters of each other to facilitate simultaneous observations. Two different pair groups were established. First, naturally occurring pairs, which were trees chosen for their natural differences in flowering level (heavy vs. light) as described above. Second, we experimentally tested whether flowering levels affect a migrant's behavior by deflowering one tree in a heavily flowering pair while leaving the unaltered second tree to serve as a control.

\section{Naturally Occurring Pairs}

In 2002 and 2003, we controlled for habitat and tree species differences between trees within a pair by performing paired observations on trees with similar surrounding flora and choosing honey mesquite trees of equal size but differing flowering levels. Thus, each pair consisted of one tree in heavy flower and one in light flower. The same phenology level described in patch arthropod sampling was assigned. Furthermore, we performed paired observations either simultaneously or within 15 minutes of one another to control for temporal differences in bird behavior. We could not control for species effect or number of bird visitations during observations. The behavioral variables that we measured were visit rate, length of stay, and attack ratio. These three variables were selected because Hutto (1990) contends that bird behavior should reflect prey availability.

We predicted that flowering attracts arthropods and, therefore, more bird visits, longer bird stays, and more bird attacks: 


\begin{tabular}{|l|l|l|}
\hline & $\begin{array}{l}\text { Heavy } \\
\text { Flowering } \\
\text { Trees } \\
\text { (Most } \\
\text { arthropods) }\end{array}$ & $\begin{array}{l}\text { Light Flowering } \\
\text { Trees } \\
\text { (Fewer } \\
\text { arthropods) }\end{array}$ \\
\hline Visit Rate & $\uparrow$ & $\downarrow$ \\
\hline $\begin{array}{l}\text { Length of } \\
\text { Stay }\end{array}$ & $\uparrow$ & $\downarrow$ \\
\hline Attack Ratio & $\uparrow$ & $\downarrow$ \\
\hline
\end{tabular}

We tested the null hypotheses that there is no mean difference in visit rate, length of stays, or attack ratio between naturally and manipulated high and low flowering trees.

Pair variables measured included: (a) length of stay (number of seconds that all birds visited during the 15 minute observation period), (b) visit rate (number of birds/15-minute observation period), and (c) attack ratio (number of seconds in attack maneuvers/total seconds in bout of all birds during a 15 minute observation period). Data were collected via a hand-held tape recorder and stopwatches. Due to unequal variances and nonnormality of these data, we used non-parametric Wilcoxon Signed Rank Tests (Wilcoxon 1945) to compare level (heavy versus light flower) means of the variables within a pair. Natural pair data for 2002 and 2003 were pooled by level given that year-to-year differences in visit rates, lengths of stay, and attack ratios were similar.

\section{Experimental flower removal}

In 2003, we chose naturally occurring honey mesquite tree pairs with equal flower and leaf levels and then removed flowers from one tree within the pair in order to: (1) remove the proximate cue (flowers) but keep the ultimate cue (arthropods) to determine if birds are tracking arthropods directly or if they are using a proximate cue, (2) experimentally exaggerate the magnitude of flowering effect, and (3) reduce the potential leaf effect because higher levels of flowering were usually associated with higher levels of leafing and could not be controlled for in the natural-pair group. The intact heavy flowering tree served as the control.

The arthropod community similar on each tree in the pair (although de-flowering probably did

\begin{tabular}{|l|l|l|}
\hline & $\begin{array}{l}\text { Heavy } \\
\text { Flowering } \\
\text { Trees } \\
\text { (same } \\
\text { arthropods) }\end{array}$ & $\begin{array}{l}\text { De-flowered } \\
\text { Trees } \\
\text { (same } \\
\text { arthropods) }\end{array}$ \\
\hline Visit Rate & $\uparrow$ & $\downarrow$ \\
\hline $\begin{array}{l}\text { Length of } \\
\text { Stay }\end{array}$ & $=$ & $=$ \\
\hline Attack Ratio & $=$ & $=$ \\
\hline
\end{tabular}

We tested the null hypotheses that there were no difference in visit rate, length of stay or attack ratio between flowering and flower-removed trees.

A flower-removed tree (treatment) was always reduced to no more than five percent bloom before bird foraging observations took place. We controlled temporal differences by simultaneously observing pairs during the 15-minute observation period. Re-sampled experimental pairs had a minimum of two days between efforts to avoid pseudoreplication. Due to unequal variances and non-normality, we utilized the non-parametric Wilcoxon Signed Rank Test (Wilcoxon 1945) to compare level means of the variables between paired comparisons.

\section{Avian Diet Sampling}

The same three focal bird species were selected for dietary analysis: Nashville warbler, Orangecrowned warbler, and Wilson's warbler. We used a modified lavage technique to acquire stomach samples (Moody 1970, Laursen 1978, Rosenberg and Cooper 1990). Warm water was drawn into a 3-cc syringe with plastic tubing affixed to the syringe head. Tubing was slowly inserted along the roof of the mouth, past the esophagus and into the crop. The bird's head was then positioned with 
the crown tilted downward over a receptacle to keep from drowning the bird. Water was pushed into the crop at a rate of a $1 \mathrm{cc} / \mathrm{sec}$. The birds usually regurgitated stomach contents into the receptacle. Each sample was washed with 70 percent ethanol directly into a vial for preservation (Frank Moore IN LITT). Prey fragments were identified to morpho-species using the arthropod reference collection compiled from our field arthropod samples. Common prey fragments that were unidentifiable to morphospecies were assigned a code until later identified (Ralph et al. 1985).

Chi Square Likelihood Ratio tests with Bonferroni adjustments (Zarr 1999, p. 461, Neter et al. 1996, p.736) were used to determine differences between mean proportions of prey items found in bird stomachs, and mean proportion of arthropods sampled from trees, at the order and morphospecies level. An indicator species analysis was conducted to determine morpho-species membership to a particular dominant riparian tree species (Dufrene and Legendre 1997 using the program PCORD). Indicator values were derived from Monte Carlo tests with values ranging from 0 (no indication) to 100 (perfect indication). Morpho-species are considered as having a significant membership to a particular tree species if the indicator value is at least 19 and having a minimum probability value of 0.02 . A second indicator species analysis was conducted to determine morpho-species membership to a particular phenology zone (i.e., flower, leaf). The indicator species method calculated the proportional abundance of a species in a group, relative to the abundance of that species in all groups.

\section{Results}

\section{Timing Level}

\section{Phenology and Avian Surveys}

When 2002 and 2003 migrant survey data $(n=162$; Table 1) were compared with our phenology data, the only significant correlation was that migrant arrivals coincided with honey mesquite flowering $(\mathrm{R}=0.76, \mathrm{p}=0.03)$ (Figure 1). Correlations for the other tree species' leaf cover and flowering compared to the relative abundance of migrants were not significant (Table 2).

Screwbean mesquite leaves emerged at the end of peak migration. Fremont cottonwood showed no pattern with migrant stopover patterns as leaf flush had long since occurred by the time the first migrants arrived. Although peak tamarisk flowering occurs after spring migration, flowers were present and leafing was almost complete during the migration period. Goodding's willow also blooms in spring, but no correlation with migrant arrival and tree phenology was detected.

\section{Patch Level}

\section{Arthropod Sampling}

For arthropod abundance, honey mesquite hosted three to four times more arthropods per sample than did Fremont cottonwood, 1.5-2 times more than Goodding's willow, and slightly more than on screwbean mesquite for two arthropod sampling sessions during peak spring migration $\left(4 / 18 / 03 ; \mathrm{F}_{3,87}=66.29, \mathrm{p}<0.00,5 / 6 / 03 ; \mathrm{F}_{3,74}=\right.$ 101.99, $\mathrm{p}<0.00$ ) (Figure 2).

For arthropod richness, honey mesquite had 3-5 times greater species richness (morpho-species) per sample than did Fremont cottonwood, 1.5-2 times more than Goodding's willow, and similar species richness as on screwbean mesquite (Figure 2 ) for the same two sampling sessions $(4 / 18 / 03 ; \mathrm{F}$ $3,87=100.20, \mathrm{p}<0.00,5 / 6 / 03 ; \mathrm{F}_{3,74}=105.01, \mathrm{p}$ $<0.00)$.

We branch sampled arthropods at the birds' predominant "attack zone," an area between 56 percent and 75 percent ( $\pm 1 \mathrm{SE}$ ) of the tree's relative height from base to crown (Table 3 ). Because less than 1 percent of the birds foraged on tamarisk trees $(0.07 \%)$, tamarisk was not included for comparisons of arthropod abundance and richness among tree species.

\section{Random Sampling of Foraging Behavior}

When available foraging substrate (based on canopy cover) was compared to substrate that birds used (based on attack maneuver data only), the three focal migrant species dominated their foraging in honey mesquite. All three birds significantly foraged disproportionately on honey mesquite when compared to what was available at 
the study site (Nashville warbler $\mathrm{X}_{3}{ }_{3}=38.54, \mathrm{p}$ $<0.00$, Orange-crowned $\mathrm{x}_{3}{ }_{3}=26.19, \mathrm{p}<0.00$, and Wilson's warblers $\mathrm{X}_{3}{ }_{3}=48.52, \mathrm{p}<0.00$ ). Other birds in the guild also disproportionately used honey mesquite, but also utilized screwbean mesquite $\left(\mathrm{X}_{3}^{2}=22.02, \mathrm{p}<0.00\right)$ (Figure 3 ). Furthermore, Nashville warbler foraged 87 percent, Orange-crowned 68 percent, and Wilson's warblers 82 percent in honey mesquite trees. Other birds in the guild had a combined foraging effort of 66.2 percent in honey mesquite. These data confirm the importance of honey mesquite trees as a primary foraging site for migrating insectivorous warblers, and justify the use of honey mesquite as a focal species to investigate microhabitat selection.

\section{Microhabitat level}

\section{Arthropod Sampling}

Mean abundance per sample of arthropods was consistently and significantly greater on heavy flowering than on light flowering honey mesquite trees in four of five sessions over two years $\left(\mathrm{F}_{4}\right.$, $\left.{ }_{150}=6.43, \mathrm{p}<0.00\right)($ Figure 4A). Mean arthropod species richness was also consistently and significantly greater on high flowering samples in four of five sessions over two years $\left(\mathrm{F}_{4,150}=\right.$ 31.17, $\mathrm{p}<0.00$ ) (Figure 4B).

Furthermore, arthropod abundance significantly increased as the honey mesquite flowering level increased $\left(r^{2}=0.41, p=0.00\right)$ (Figure 5). Similarly, arthropod richness increased as the flowering index increased $\left(r^{2}=0.32, p=0.00\right)$.

We collected 172 different morpho-species from honey mesquite branch samples. These samples were collected from the birds "attack zone" as described earlier. In 200273 morpho-species were collected, with an additional 99 morpho-species in 2003. A total of 12 arthropod orders were represented.

\section{Random Sampling of Avian Foraging Behavior}

Among honey mesquite trees in 2002, all three focal species (Nashville warbler $n=10$, Orangecrowned warbler $n=12$, Wilson's warbler $n=27$ ) tended to forage in trees with higher than average flowering levels, but only Wilson's warbler did so significantly in $2002(\mathrm{Z}=-4.52, \mathrm{p}=0.00)$ (Figure
6A). The "other" birds $(n=18)$ tended to forage in trees with higher flowering levels than the average stand flowering level in $2002(Z=-1.72, p=0.08)$ (Figure 6A).

In 2003, all three focal species (Nashville warbler $n=32$, Orange-crowned warbler $n=21$, Wilson's warbler $n=32$ ) foraged in trees with significantly higher flowering levels than the average stand flowering level $(Z=-4.45, p=0.00, Z=-3.63$, $p=$ $0.000, Z=-3.06, p=0.00$ respectively). Similarly, the "other" birds $(n=15)$ also foraged in trees with significantly higher flowering levels than the average stand flowering level $(Z=-2.39, p=0.02)$ (Figure 6B).

Only flowering phenology data are presented hereafter, because leaf and flower levels were autocorrelated (e.g., more leafing equals more flowering as trees develop throughout spring) $(\mathrm{R}=$ $0.84, \mathrm{p}=0.00$ ).

\section{Avian Foraging Behavior at Paired Flowering Levels}

\section{Naturally Occurring Pairs}

Mean visit rate of the three focal bird species was over three times greater on heavy, than on light flowering trees in naturally occurring paired tree trials $(Z=-3.05, p=0.00, n=49)$. Mean length of stay was over four times longer on heavy flowering trees $(Z=-3.00, p=0.00, n=49)$, and mean attack ratio was three times greater on heavy flowering trees, $(\mathrm{Z}=-3.39, \mathrm{p}=0.00, \mathrm{n}=49)$ (Figure 7 A, B, C). Sample sizes for individual species comparisons were too small for the three focal species; trends for 2002 and 2003 were similar before pooling.

Thirteen "other" migrant leaf-gleaning insectivorous species (Table 1) showed a similar trend for the three representative warblers for all tests, but only length of stay was significantly greater on heavy flowering trees $(\mathrm{Z}=-2.48, \mathrm{p}$ $=0.00)($ Figure $8 \mathrm{~A}, \mathrm{~B}, \mathrm{C})$.

\section{Experimental flower removal}

For the three focal birds, mean visit rate was four times greater on heavy flowering than de-flowered treatments in experimental paired tree trials $(\mathrm{Z}=$ $3.08, \mathrm{p}=0.00, \mathrm{n}=34)$. There were no significant differences in mean lengths of stay on heavy 
flowering versus de-flowered tree treatments $(\mathrm{Z}=$ $-1.93, p=0.06, n=34)$. Mean attack ratio was over three times greater on heavy flowering than on deflowered treatments $(Z=-2.04, p=0.04, n=34)$

(Figure 7 A, B, C).

Thirteen "other" migrant leaf-gleaning insectivores (Table 1) had similar behavioral trends in visit rate, length of stay, and attack rate, to the three representative warblers, but no significant differences were detected between treatments $(n=34)$ (Figure 8 A, B, C).

\section{Avian Diet Sampling}

The proportion of prey items found in the diets of the three species was significantly different from what was available in the environment, by order and morpho-species level of identification (Table 4). Analysis of stomach contents among the members of this guild demonstrated that each bird selected, as it's primary prey, different orders and morpho-species. By order-level classification, Nashville warblers ate the most Hemipterans, Orange-crowned the most Homopterans, and Wilson's warbler the most Coleopterans and Dipterans (Figure 9). At the morpho-species level of classification, Hom 6, an herbivore, was the most common insect in all three diets. Nashville warblers ate the most Hem 7's, Orange-crowned ate the most Hom 6's and Hem 7's, and Wilson's warbler ate the most Dip 17's and Hom 6's (Figure 10).

Furthermore, the proportion of prey items found in the diets of the three species was significantly different from each other in two sessions by order and morpho-species level of identification (Table 5). Ten morpho-species were significantly affiliated with honey mesquite trees, while two were significantly affiliated with screwbean mesquite. There were no other significant affiliations to other tree species (Table 5). Of the 19 morpho-species identified in diets, seven were significantly affiliated with the flowering condition (Table 6). These seven arthropod species comprised 63-86 percent of Nashville warbler diets, 51-74 percent of Orange-Crowned diets, and over 78 percent of Wilson's warbler diets in 4/18/200 and 5/6/2003 sampling sessions respectively (Figure 11).
Although the two arthropod sampling sessions were just two weeks apart, there were significant differences in the proportions of arthropods between the two sampling sessions at the order and morpho-species level $\left(\mathrm{X}_{8}^{2}=436.78, \mathrm{p}<0.00\right.$, $\mathrm{X}^{2}{ }_{18}=1264.59, \mathrm{p}<0.00$ respectively). Therefore, stomach contents and arthropod samples collected within a day of each other were analyzed as a unit and not pooled between the two sessions.

We identified nine orders of arthropods in the diets of the three representative insectivores. At the order level, Lepidoptera and Araneae fragments found in the diets were not identifiable to morpho-species and are only represented by order classification. Approximately 50 percent of fragments were identified to morpho-species. An estimated 30 percent of prey items found in the diets of these birds could not be identified to the level of morpho-species, but could be identified to order, and an estimated 20 percent of all fragments were unidentifiable.

\section{Discussion}

Insectivorous migrant leaf-gleaning birds consistently arrive at Cibola NWR when honey mesquite flowering trees reach peak bloom. While at this spring stopover site, they forage primarily on tree species that bloom and host significantly more insects than other riparian tree species. Within the flowering patch, migrants forage on trees with the highest levels of bloom and are tracking the relative high prey abundances associated with flowering. Finally, over half of the diets of the three representative insectivores consisted of prey significantly associated with honey mesquite flowering.

\section{Timing Level: Migrant Arrivals Associated with Tree Phenology}

The only significant phenological correlation that we detected was that migrant arrivals coincided with honey mesquite flowering. These data demonstrate that migrant bird numbers consistently crest when site flowering is in peak bloom. It is thus apparent that bird use of this stopover site correlates each year with honey mesquite flowering. Whether migrants are timing their arrivals at this stopover site based on 
latitudinal advances in spring tree phenology, or, alternatively, whether honey mesquite has evolved to time its peak bloom with peak insect predation by avian insectivores remains to be determined.

We have demonstrated that flowering attracts arthropods. The costs of flower advertisement may also attract insect herbivores. At least one quarter of the diets of each of the three warblers in the leaf-gleaning insectivorous guild contained insect herbivores. Honey mesquite trees would benefit from decreased insect herbivory by producing flowers when a significant herbivore predator is present, thereby reducing the cost of such advertisement. Prey not taken in high numbers by this avian guild are pollinators such as bees and wasps. These fast-flying insects are not typically hunted by warblers because catching them requires a hunt-on-the-wing type of maneuver that is not commonly observed for warblers.

Different age and sex categories of the same bird species often migrate at different dates, potentially explaining differences in stopover timing. For example, Wilson's warbler stopover patterns were predominantly sex-related in spring and agerelated in fall (Yong, et al. 1998). Kelley et al. (2002) described leapfrog-style migration where isotope analysis demonstrated that those Wilson's warblers which bred furthest north, migrated earliest in the autumn. In addition, birds may time stopovers based on site fidelity. Migrating Reed Warblers in Bet Shean Valley, Israel, had the same recapture rate as summer residents, indicating stopover site fidelity (Merom 2000). Although there may be many factors regulating the timing of arrivals at stopover sites by spring migrating insectivorous birds, this study appears to be the first to tie migration stopover timing with spring plant phenological patterns.

\section{Patch level: Habitat Decisions Associated with Tree Phenology}

There are many examples of birds tracking resources at the patch level. For example, in a study on the lower Colorado River, Rice (1984) found that although cottonwood-willow provided dominant habitats for birds year round, it was equaled in avian species richness by honey mesquite dominated habitat in spring. Hutto
(1980) documented insect concentrations were four times greater in edge than interior habitat, and migratory insectivorous bird density was, correspondingly, five times greater in edge than interior habitats in southeastern Arizona. On the Upper Colorado River, Yard et al. (2004) found honey mesquite-dominated habitat contained higher arthropod diversity and better "quality" prey items than adjacent tamarisk-dominated habitat during the breeding season. Our study demonstrated that arthropod abundance is nearly two times greater on trees with the heaviest flowering, suggesting that insects and hence migrating birds may be attracted to flowering patches to utilize high insect prey resources. Birds disproportionately foraged on honey mesquite when compared to all other tree species present, especially considering that honey mesquite only accounts for $25 \%$ of the canopy coverage at this location.

Why would insects be attracted to flowering patches? The Resource Diversity Hypothesis (Thompson 1978) states that the more resources available for insect herbivores, the higher the abundance and diversity of those herbivores. In his study, isolated parsnip plants had several distinct aboveground plant parts (e.g., flowers, stems, buds) available over a longer period of time than dense patches of parsnip. The Resource Concentration Hypothesis proposed by Root (1973) states that herbivorous insects will locate and colonize host plants that are concentrated spatially and temporally, and that they will experience reproductive success that results in higher populations. The availability of resources to arthropods, whether by offering more plant parts as described by Thompson (1978) or a dense vegetation patch which herbivores are more likely to find and colonize as described by Root (1973), may both be true at this site. Flowering honey mesquite offers more of certain plant parts (i.e., young leaves and flowers) than any other dominant riparian tree. Furthermore, honey mesquite is not a completely synchronized blooming species with dense patches of blooming and leafing interspersed throughout the site. Because of temporal and spatial patch dynamics and variety in above ground plant parts, insect herbivores may experience both success in locating vegetation patches and then increased reproductive success. 
When migrant numbers are high in patches, insect reduction caused by bird predators may be appreciable. Many studies have shown birds significantly reduce insect numbers (Holmes et al. 1979, Atlegrim 1989, Marquis and Whelan 1994, Floyd 1996, Strong et al. 2000), but none have reported whether the timing of these reductions during spring migration is beneficial to a plant. Migrant arrivals at this stopover are temporally staggered as different species arrive at different times during spring (Rosenberg et al. 1991). This staggering may result in a mutually beneficial situation where arthropod numbers recover enough after each bout of avian predation to continue to provide prey for birds, but not enough to achieve levels that would be harmful to the tree. Birds are sensitive to prey densities and key in on very specific insect population traits (MacArthur and Pianka 1966, Zach and Falls 1976). This study demonstrates that when flowering mesquite levels increase, so does arthropod abundance and richness.

\section{Microhabitat level: Habitat Decisions Associated with Tree Phenology}

Hutto (1990) argued that prey availability and avian feeding rate should be proportional to prey/food density. When he experimentally reduced spruce budworm larvae, a predominant food item for forest passerines in early summer in Washington and Montana, the mean attack rate was significantly greater in trees with more prey. Hutto (1990) cites numerous other studies with similar results (e.g., Greenwood and Harvey 1978, Tinbergen 1981). Our results from both paired tree observations and flower-manipulated experiments demonstrated that migrants' mean attack ratio was significantly higher in trees with heavy flowering for the three focal species. Migrant birds that were pooled and termed "other," showed a similar higher attack ratio in heavy flowering trees. Our mean arthropod abundance and richness data are significantly higher on trees with elevated flowering levels and is consistent with the bird attack ratios, indicating that birds are tracking food densities. These results support Hutto's argument that prey availability and feeding rate should be proportional to food density, as bird attack behavior and insects were greatest on heavy flowering trees.

Hutto (1990) also tested the probability of a bird visiting a coniferous tree and the mean duration of a bird's stay in paired tree observations. He found that birds did not significantly respond to trees with more food, although the trend was to stay longer in trees with higher prey densities. Conversely, our results from natural paired tree observations demonstrated that migrants' mean visit rates are significantly greater on heavy flowering trees. Unlike the trees in Hutto's experiment, the trees that we altered were left with many insects after flowers were removed, possibly contributing to the insignificant lengthof-stay pattern.

Our visit rate data reveals an important difference from Hutto's (1990) study. His paired trees were probably visually similar to birds. He systemically reduced insects on one tree within a pair by injecting insecticide into the tree. Insects in his study are the ultimate cue, food, whereas in this study, we eliminated the proximate cue, the flowers. In eliminating the proximate cue, the visit rate was significantly less on trees with either no flowers or low amounts of flowers. The visit rate data suggests flower cueing by these birds. The significantly longer duration of stay is likely indicative of the abundant and rich arthropod resources. When we experimentally removed flowers, birds still preferentially visited heavy flowering trees over light flowering trees even though arthropod numbers were similar between trees. Given the corroboration of these data, flowering appears to trigger a settling response at the patch and tree level for the three focal migrants, with similar trends for "other" insectivorous birds.

We have demonstrated migrant insectivorous warblers disproportionately forage on flowering honey mesquite trees at this stopover site in spring. This tree species is a conspicuous landscape feature in spring with flowering trees offering yellow flowers that are visible at long distances. Finding evidence of insects associated with these flowers in the diets of these bird's further supports the concept of visual cueing. 


\section{Avian Diets}

Diet analyses in studies of avian ecology are under-represented, and most studies take the level of identification of stomach and fecal contents only to order (e.g., Chapman and Rosenberg 1991, Lefebvre and Poulin 1996, Marchetti et al. 1998, Burger et al. 1999), and even fewer to family (but see Laursen 1978, Weins and Rotenberry 1987). By identifying prey to the morpho-species level, we were able to determine the degree of affiliation that a prey species had to a specific phenological condition. In examining the diets of the three representative birds using an indicator species analysis, we present evidence that over half of their diets consist of insects significantly associated with flowering. Whether the insect is a flowering obligate such as insects in the order Thripdae (thrips), or a predator of thrips, such as Anthocorid, and Thomicid spiders, these birds include them in their diet. Some softer-bodied insects such as thrips (which are also very small, $>0.05 \mathrm{~mm}$ ), spiders and lepidopteran larvae may not have shown up in diet samples as readily as harder, more scleratized parts, such as a beetle carapace, and have been considered underrepresented by other researchers (Rosenberg and Cooper 1990). However, spiders and lepidoptera larvae possess scleratized parts such as fangs and mandibles, so we were able to identify hard and soft-bodied insects equally well to order. An estimated 40 percent of prey items found in the diets of these birds could not be identified to the level of morpho-species. Unidentified parts could have been internal structures and may have been from a species already identified. Even though sample sizes were small, and caution should be taken in interpreting results, the foraging behavior that we recorded for these birds corroborates our diet findings.

MacArthur (1958) was the first to show that wood warblers from the same foraging guild partition resources based on foraging behavior and feeding location during the breeding season. Because we controlled for temporal differences in insect availability and differences in stopover arrivals of birds by collecting diet, foraging, and insects samples at the same time, the significant differences in diets among the three birds suggest that western migrating warblers are also partitioning resources. Laursen (1978) found prey segregation by sylviine warblers at a spring stopover in Denmark. He reports that where food was abundant, prey selection did not differ significantly among sylviine warblers, but when many birds were present, warblers segregated prey.

Jones et al. (2000) and Schwiltch et al. (2001) report insectivorous migrants feeding on the nectar and pollen of flowering trees at stopover sites. We found anthers and other plant parts in diet samples, although they may have been incidental to the taking of insect prey. Flowering trees that provide insectivorous birds with nectar and pollen, as well as insects, further support our hypothesis that flowering cues insectivorous leafgleaning migrants to profitable microhabitats that maximize refueling requirements. Profitability is a question that merits future investigation.

\section{Management Implications}

Refuges along the lower Colorado River corridor provide some of the last remaining native riparian habitat in the southwestern United States (Rosenberg et al. 1991). Declines in riparian habitat and declines of western migratory birds (Askins et al. 1990) associated with riparian habitats may be related. Research on mechanisms that migrant birds use to locate food while in transit is rare. Even more scarce is research on western songbird migration and the stopover habitat needs of western insectivores.

We feel that data from our study fill an important gap in the research on western migration because we have identified one of the cues that migrating birds use to locate food. Our data demonstrate the importance of flowering trees in providing birds with critical habitat needs during the spring migration, and suggest that the importance of preserving spring-flowering riparian tree species must be considered by land managers on the lower Colorado River. This information can be used as an important component of the many proposed revegetation projects slated for upcoming years on the Colorado River. 


\section{Literature Cited}

Atlegrim, O. 1989. Exclusion of birds from bilberry stands: impact on insect larval density and damage to the bilberry. Oecologia 79: 136-139.

Askins, R.A., J.F. Lynch, and R. Greenberg. 1990. Population declines in migratory birds in eastern North America. Current Ornithology $7: 1-57$.

Bell, W.J. 1991. Searching behaviour: the behavior ecology of finding resources. Chapman and Hall, London, UK.

Bell, G.W., S.J. Hejl, and J. Verner. 1990. Proportional use of substrates by foraging birds: model considerations on first sightings and subsequent observations. Studies in Avian Biology 13:161-165.

Block, W.M., and L.A. Brennan. 1993. The habitat concept in ornithology: theory and applications. Pages 35-91 in D.M. Powers, editor. Current Ornithology, Volume 11. Plenium Press, New York, NY, USA.

Borror, D. J., C. A. Triplehorn, and N. F. Johnson. 1989. An introduction to the study of insects, $6^{\text {th }}$ edition. Brooks/Cole Thompson Learning Inc. New York, N.Y, USA.

Bradley D.W. 1985. The effects of visibility bias on time-budget estimates of niche breadth and overlap. Auk 102:493-499.

Burger, J. C, M. A Patten, J. T Rotenberry, and R. A. Redak. 1999. Foraging ecology of the California gnatcatcher deduced from fecal samples. Oecologia 20(2):304-310.

Chapman A. and K. V. Rosenberg. 1991. Diets of four sympatric Amazonian woodcreepers (Dendrocolaptidae). Condor 93 (4): 904-915.

Connell, J.H. 1975. Some mechanisms producing structure in natural communities: a model and evidence from field experiments. Pages 460490 in M.L. Cody and J.M. Diamond, editors. Ecology and Evolution of Communities. Belknap Press, Cambridge, Massachusetts, USA.

Dufrene, M. and P. Legendre. 1997. Species assemblages and indicator species: the need for a flexible asymmetrical approach. Ecological Monographs 67:345-366.

Finch D.M., and W. Yong. 2000. Landbird migration in riparian habitats of the Middle Rio Grande: a case study. Pages 88-98 in F.R. Moore, editor. Stopover Ecology of NearcticNeotropical Landbird Migrants: Habitat Relations and Conservation Implications. Studies in Avian Biology No. 20. Cooper Ornithological Society, University of California, CA.

Floyd, T. 1996. Top-down impacts on creosotebush herbivores in a spatially and temporally complex environment. Ecology 77: 1544-1555.

Games P.A., and J. F. Howell. 1976. Pairwise multiple comparison procedures with unequal n's and/or variances: A Monte Carlo study. Journal of Educational Statistics 1:113-125.

Gauthreaux, S.A. 1971. A radar and direct visual study of passerine spring migration in

Gauthreaux, S.A. 1972. Behavioral responses of migrating birds to daylight and darkness: a radar and direct visual study. Wilson Bulletin 84:136-148.

Greenberg, R.S. 1985. A comparison of foliage discrimination learning in a specialist and a generalist species of migrant wood warbler (Aves: Parulidae). Canadian Journal of Zoology 63:773-776.

Greenwood, P.J., and P. H. Harvey. 1978. Foraging and territory utilization of Blackbirds (Yurdis merula) and Song Thrushes (Turdis philomelos). Animal Behavior 26:1222-1236.

Hertz, P.E., J.V. Remsen, Jr., and S.I. Zones. 1976. Ecological complementarity of three sympatric parids in a California oak woodland. Condor 78:307-316.

Hildén, O. 1965. Habitat selection in birds: a review. Ann. Zool. Fenn. 2:53-75.

Holmes, R. T., Schultz, J. C. and Nothnagle, P. 1979. Bird predation on forest insects: an exclosure experiment. -Science 206: 592-602.

Hutto, R.L. 1980. Winter habitat distribution of migratory land birds in western Mexico, with 
special reference to small, foliage-gleaning insectivores. Pages 181-203 in A. Keast and E.S. Morton, eds. Migrant birds in the neotropics: ecology, behavior, distribution, and conservation. Random House (Smithsonian Institution Press), New York.

Hutto, R.L. 1981. Temporal patterns of foraging activity in some wood warblers in relation to the availability of insect prey. Behavioral Ecology and Sociobiology 9(3):195-198.

Hutto, R.L. 1985a. Habitat selection by nonbreeding, migratory land birds. Pages 455476 in M.L. Cody, editor. Habitat Selection in Birds. Academic Press, Inc.

Hutto, R.L. 1985b. Seasonal Changes in the habitat distribution of transient insectivorous birds in south-eastern Arizona: competition mediated? Auk 102:120-132.

Hutto, R.L. 1990. Studies of foraging behavior: central to understanding the ecological consequence of variation in food abundance. Studies in Avian Biology 13: 389-390.

Hutto, R.L. 1998. On the importance of stopover sites to migrating birds. Auk 115(4):823-825.

Johnson, D.H. 1980. The comparison of usage and availability measurements for evaluating resource preference. Ecology 61:65-71.

Johnson, M. D. 2000. Evaluation of an arthropod sampling technique for measuring food availability for forest insectivorous birds. Journal of Field Ornithology 88-109.

Jones, J., P.R. Perazzi, E.H. Carruthers, and R.J. Robertson. 2000. Sociality and foraging behavior of the Cerulean warbler in Venezuela shade-coffee plantations. Condor 102:958-962.

Kelly, J. I., V. Atudorei, Z. I. Sharp, and D. I. Finch. 2002. Insights into Wilson's Warbler migration from analyses of hydrogen stableisotope ratios. Oecologia 130:215-221.

Klopfer, P.H., and J.U. Ganzhorn. 1985. Habitat selection: behavioral aspects. Pages 436-454 in M.L. Cody, editor. Habitat Selection in Birds. Academic Press, Orlando, Florida, USA.
Kuenzi, A.J., F.R. Moore, and T.R. Simons. 1991. Stopover of Neotropical landbird migrants on East Ship Island following trans-Gulf migration. Condor 93:869-883.

Laursen K. 1978. Interspecific relationships between some insectivorous passerine species, illustrated by their diet during spring migration. Ornis Scandinavica 92:178-192.

Lefebvre, G. and B. Poulin. 1996. Seasonal abundance of migrant birds and food resources in Panamanian mangrove forests. Wilson Bulletin 108(4):748-759.

Lindstrom, A. 1995. Stopover ecology of migrating birds: some unsolved questions. Israel Journal of Zoology 4:407-416.

Lynn, S.E., and A.L. Averill. 1996. Neotropical Migratory Bird Monitoring Project in the Lower Colorado River Valley, Final Report 1994-1995. University of Arizona. 252 pp.

MacArthur, R. H. 1958. Population ecology of some warblers of northeastern coniferous forests. Ecology. 39(4):559-619.

MacArthur, R.H., and E.R. Pianka. 1966. On the optimal use of a patchy environment. American Naturalist 100:603-609.

Marchetti, C., D. P Locatelli, A. J Van Noordwijk, and N. E. Baldaccini. 1998. The effects of prey size on diet differentiation of seven passerine species at two spring stopover sites. Ibis140(1):25-34.

Marques De Alckmin, E. S., P.W. Price, and N.S. Cobb. 2000. Resource abundance and insect herbivore diversity on Fabaceous desert plants. Environmental Entomology 29(4):696703.

Marquis, R. J. and Whelan, C. J. 1994. Insectivorous birds increase the growth of white oak through consumption of leafchewing insects. Ecology 75: 2007-2014.

Merom, K., Y. Yom-Tov, and R. McClery. 2000. Philopatry to stopover site and body condition of transient reed warblers during autumn migration through Israel. Condor 102 (2): 441-444. 
Moody D.T. 1970. A method for obtaining food samples from insectivorous birds. Auk 81:579.

Moore, F. R. and T. R. Simmons. 1992. Habitat suitability and stopover ecology of neotropical landbird migrants. Pages 345-355 in J. M. Hagen, III and D. W. Johnson, editors. Ecology and conservation of neotrpical migrant landbirds. Smithsonian Institution Press, Washington, D. C.

Moore, F.R., S.A. Gauthreaux, Jr., P. Kerlinger, and T.R. Simons. 1993. Stopover habitat: management implications and guidelines. Pages 58-69 in D.M. Finch and P.W. Stangel, editors. Status and management of neotropical migratory birds. USDA Forest Service General Technical Report RM-229. USDA Forest Service Rocky Mountain Forest and Range Experiment Station, Ft. Collins, CO.

Moore, F.R., S.A. Gauthreaux, Jr., P. Kerlinger, and T.R. Simons. 1995. Habitat requirements during migration: important link in conservation. Pages 121-144 in T.E. Martin and D.M. Finch, editors. Ecology and management of neotropical migratory birds: a synthesis and review of critical issues. Oxford University Press, New York, NY.

Moore, F.R., and D.A. Aborn. 2000. Mechanisms of en route habitat selection: how do migrants make habitat decisions during stopover? Studies in Avian Biology 20:34-42.

Moore, F.R. and P. Kerlinger. 1987. Stopover and fat deposition by North American wood warblers (Praulinae) following spring migration over the Gulf of Mexico. Oecologia 74:47-54.

Morris, R.F., W.F. Cheshire, C.A. Miller, and D.G. Mott. 1958. The numerical response of avian and mammalian predators during gradation of spruce budworm. Ecology 39:487-494.

Neter, J, M. H. Kutner, C.J. Nachtsheim, W. Wasserman. 1996. Applied Liner Statistical Models. $4^{\text {th }}$ ed. WCB McGraw Hill

Noon, B.R. 1981. The distribution of an avian guild along a temperate elevational gradient: the importance and expression of competition. Ecological Monographs 51:105-124.

Parrish, J.D. 2000. Behavioral, energetic, and conservation implications of foraging plasticity during migration. Studies in Avian Biology 20:53-70.

Pyke, G.H., H.R. Pulliam, and E.L. Charnov. 1977. Optimal Foraging: a selective review of theory and tests. The Quarterly Review of Biology 52(2):137-154.

Ralph C.P., S.E. Nagata, and C.J. Ralph. 1985. Analysis of droppings to describe diets of small birds. Journal of Field Ornithology $56: 168-174$.

Rappole, J.H. 1995. The ecology of migrant birds: a neotropical perspective. Smithsonian Institution Press, Washington, D.C. 269 pp.

Rappole, J.H. 2000. Birds of the Southwest: Arizona, New Mexico, southern California and southern Nevada. Texas A\&M University Press, College Station, TX. 329 pp.

Reynolds, R.T., J.M. Scott, and R.A. Nussbaum. 1980. A variable circular-plot method for estimating bird numbers. Condor 82:309-313.

Rice, J., B.W. Anderson, and R.D. Ohmart. 1980. Seasonal habitat selection by birds in the lower Colorado River Valley. Ecology 61:1402-1411.

Rice, J., B.W. Anderson, and R.D. Ohmart. 1984. Comparison of the importance of different habitat attributes of avian community organization. Journal of Wildlife Management 48:895-911.

Root, R.B. 1967. The niche exploitation pattern of the Blue-gray Gnatcatcher. Ecological Monographs 37:317-350.

Root, R.B. 1973. Organization of a plantarthropod association in simple and diverse habitats: the fauna of collards (Brassica oleracea). Ecological Monographs 43:95-124.

Rosenberg, K.V. and R.J. Cooper. 1990. Approaches to avian diet analysis. Pages 8090 in M.L. Morrison, C.J. Ralph, J. Verner, and J.R. Jehl Jr., editors. Avian foraging: theory, methodology, and applications. Studies in Avian Biology No. 13. 
Rosenberg, K.V., R.D. Ohmart, W.C. Hunter, and B.W. Anderson. 1991. Birds of the Lower Colorado River Valley. The University of Arizona Press, Tucson, AZ. 416 pp.

Schwiltch, R., R. Mantovani, F. Spina, and L. Jenni. 2001. Nectar consumption of warblers after long-distance flights during spring migration. Ibis 143:24-32.

Sherry, T.W., and R.T. Holmes. 1988. Habitat selection by breeding American Redstarts in response to a dominant competitor, the Least Flycatcher. Auk 105:350-364.

Skagen, S.K., C.P. Melcher, W.H. Howe, F.L. Knopf. 1998. Comparative use of riparian corridors and oases by migrating birds in Southeast Arizona. Conservation Biology 12:896-909.

SPSS Inc. 2001. Version 10.0. Headquarters, Chicago, IL.

Stevens, L., B.T. Brown, J.M. Simpson, and R.R Johnson. 1977. The importance of riparian habitat to migrating birds. Pages 156-164 in R.R. Johnson and D.A. Jones, editors. Importance, Preservation and management of riparian habitat: a symposium. General Technical Report, RM-43, Fort Collins CO, U.S.

Strong, A. M., Sherry, T. W. and Holmes, R. T. 2000. Bird predation on herbivorous insects: indirect effects on sugar maple saplings. Oecologia 125: 370-379.

Sturman, W.A. 1968. The foraging ecology of Parus atricapillus and P. rufescens in the breeding season, with comparisons with other species of Parus. Condor 70:309-322.

Thompson, J.N. 1978. Within-patch structure and dynamics in Pastinaca sativa and resource availability to a specialized herbivore. Ecology 59:443-448.

Tinbergen, J. M. 1981. Foraging decisions in Starlings (Sturnus vulgaris). Ardea 69:1-67.

van Riper, C., III. 1980. The phenology of the dryland forest of Mauna Kea, Hawaii, and the impact of recent environmental perturbations. Biotropica 12:282-291.

van Riper, C., III. 1984. The influence of nectar resources on nesting success and movement patterns of the Hawaii Amakihi (Hemignathus virens). Auk 101(1):38-46.

Wauer, R.H. 1977. Significance of Rio Grande riparian systems upon the avifauna. Pages 156-164 in R.R. Johnson and D.A. Jones, editors. Importance, Preservation and management of riparian habitat: a symposium. General Technical Report, RM-43, Fort Collins CO, U.S.

Weins, J.A. 1983. Avian community ecology: an iconoclastic view. Pages 355-403 in A.H. Brush and G.A. Clark, Jr., editors. Perspectives in Ornithology. Cambridge University Press, Cambridge, United Kingdom.

Weins, J.A. and J.T. Rotenberry 1987. Diet relationships among North American grassland and shrubsteppe birds. Oecologia 42:253-292.

Whelan, C.J. 2001. Foliage structure influences foraging of insectivorous forest birds: an experimental study. Ecology 82:219-231.

Wilcoxon, F. 1945. Individual Comparisons by Ranking Methods. Biometrics 1:80-83.

Yard, H. K., C. van Riper III, B. T. Brown, and M. J. Kearsley. 2004. Diets of insectivorous birds along the Colorado River in Grand Canyon, Arizona. Condor 106:106-115.

Yong, W, D.M. Finch, F.R. Moore, and J. F. Kelly. 1998. Stopover ecology and habitat use of migratory Wilson's Warblers. Auk 115(4):829-842.

Zach R., and B.J. Falls. 1976. Ovenbirds (Aves:Parulidae) hunting behavior in a patchy environment: an experimental study. Canadian Journal of Zoology 54:1863-1879.

Zarr, J. H. 1999. Biostatistical Analysis. $4^{\text {th }}$ ed. Prentice-Hall, Engelwood Cliffs, NJ. 
Table 1. Migratory birds assigned to the leaf-gleaning insectivorous guild that used Cibola NWR, Arizona as stopover habitat during spring migration 2002 and 2003.

\begin{tabular}{|c|c|c|c|c|c|c|c|c|}
\hline & & & & & & & Pair date & \\
\hline Family & Scientific Name & Common Name & AOU code & Other birds & Survey & Foraging & Natural & $\overline{\text { Experimental }}$ \\
\hline \multirow[t]{11}{*}{ Parulidae } & Vermivora ruficapilla & Nashville warbler & NAWA & & 20 & 46 & 29 & 9 \\
\hline & Vermivora celata & Orange-crowned warbler & OCWA & & 41 & 48 & 30 & 10 \\
\hline & Wilsonia pusilla & Wilson's warbler & WIWA & & 39 & $\mid 58$ & 27 & 7 \\
\hline & Dendroica nigrescens & Black-throated grey warbler & BTYW & \# & 12 & $\mid 19$ & | 3 & 1 \\
\hline & Vermivora luciae & Lucy' warbler & LUWA & |* & 9 & 5 & 5 & 2 \\
\hline & Oporornis philadelphia & MacGillivary's warbler & MGWA & \# & | 3 & 6 & 4 & 0 \\
\hline & Dendroica townsendi & Townsend's warbler & TOWA & * & 0 & 22 & $\mid 1$ & 0 \\
\hline & Dendroica occidentalis & Hermit warbler & HEWA & ** & | 0 & 10 & 0 & 0 \\
\hline & Dendroica petechia & Yellow warbler & YEWA & |* & | 0 & 0 & $\mid 1$ & 0 \\
\hline & Geothlypis trichas & Common Yellowthroat & COYE & * & 18 & 0 & 0 & 1 \\
\hline & Ictera virens & Yellow-breasted chat & $\mathrm{YBCH}$ & |* & 9 & $\mid 1$ & 0 & 2 \\
\hline Cardinalidae & Passerina amoena & Lazuli bunting & LABU & ** & | 0 & | 0 & 2 & 0 \\
\hline \multirow[t]{2}{*}{ Vireonidae } & Vireo plumbeus & Plumbeous vireo & PLVI & |* & 4 & || 0 & $\mid 1$ & 0 \\
\hline & Vireo gilvus & Warbling vireo & WAVI & ** & |7 & 8 & 4 & 0 \\
\hline TOTALS & & & & & 162 & 223 & 107 & 32 \\
\hline
\end{tabular}

Notes: AOU refers to the American Ornithological Union standard bird codes. Shading refers to the three bird species used as representatives of the leaf-gleaning insectivorous guild. Birds termed "Others" were pooled in analyses. Numbers in columns indicate how many birds in each data set. 
Table 2. Pearson's Correlations for phenology of the dominant riparian tree species by the relative abundance of migrants.

Data from Spring 2002 and 2003, Cibola NWR, Arizona.

\begin{tabular}{lllll} 
SUBSTRATE & \multicolumn{2}{l}{ \% Leaf by Migrant \#'s } & \multicolumn{2}{l}{ \% Flower by Migrant \#'s } \\
& $\mathrm{R}$ & $\mathrm{p}$ & $\mathrm{R}$ & $\mathrm{p}$ \\
Fremont cottonwood & -0.04 & 0.94 & -0.33 & 0.42 \\
honey mesquite & 0.47 & 0.24 & 0.76 & 0.03 \\
screwbean mesquite & 0.37 & 0.37 & -0.25 & 0.55 \\
tamarisk & 0.44 & 0.27 & 0.61 & 0.11 \\
Goodding's willow & 0.08 & 0.85 & 0.12 & 0.79
\end{tabular}

note: Shading indicates significant correlation. 
Table 3. Based on first attack maneuvers; A) Relative heights of bird foraging locations among all tree species * B) Relative heights of bird foraging locations in honey mesquite.

Data pooled for spring 2000-2003 from Cibola NWR, Arizona.

\begin{tabular}{llll}
\hline \hline A) All Trees & \multicolumn{3}{l}{ Mean relative } \\
SPECIES & $\mathrm{N}$ & height & $\mathrm{SE}$ \\
\hline Lucy's Warbler & 38 & 0.75 & 0.03 \\
Black-throated grey Warbler 37 & 0.71 & 0.04 \\
Yellow Warbler & 27 & 0.66 & 0.05 \\
Townsend's Warbler & 29 & 0.67 & 0.06 \\
Orange-crowned Warbler & 152 & 0.64 & 0.02 \\
Nashville Warbler & 68 & 0.65 & 0.03 \\
Wilson's Warbler & 196 & 0.56 & 0.02
\end{tabular}

\section{B) honey mesquite}

\begin{tabular}{lcll} 
& \multicolumn{3}{l}{ Mean relative } \\
SPECIES & $\mathrm{N}$ & height & $\mathrm{SE}$ \\
\hline Lucy's Warbler & 13 & 0.74 & 0.07 \\
Black-throated grey Warbler 31 & 0.70 & 0.04 \\
Yellow Warbler & 15 & 0.63 & 0.07 \\
Townsend's Warbler & 22 & 0.80 & 0.05 \\
Orange-crowned Warbler & 73 & 0.66 & 0.03 \\
Nashville Warbler & 57 & 0.63 & 0.03 \\
Wilson's Warbler & 120 & 0.58 & 0.02
\end{tabular}

Note: * refers to tree species; Freemont cottonwood, honey mesquite, screwbean mesquite, Tamarisk, and Goodding's willow. 
Table 4. Chi-Square values comparing the proportion of arthropods found in diets versus available arthropods by order and by morpho-species* level of identification.

Data collected in spring 2003 at Cibola NWR, Arizona.

\begin{tabular}{|c|c|c|c|c|c|c|c|}
\hline \multirow[t]{2}{*}{ Date } & \multirow[t]{2}{*}{$\begin{array}{l}\text { Level of } \\
\text { identification }\end{array}$} & \multicolumn{2}{|c|}{ Nashville Warbler } & \multicolumn{2}{|c|}{ Orange-Crowned Warbler } & \multicolumn{2}{|c|}{ Wilson's Warbler } \\
\hline & & $\mathrm{X}^{2}$ & $\mathrm{p}$ & $\mathrm{X}^{2}$ & $\mathrm{p}$ & $X^{2}$ & $\mathrm{p}$ \\
\hline \multirow[t]{2}{*}{$4 / 18 / 2003$} & Order & $\mathrm{X}_{8}^{2}=176.069$ & $<0.001$ & $\mathrm{X}_{8}{ }_{8}=437.417$ & $<<0.001$ & & \\
\hline & Morpho-species & $\mathrm{X}_{17}^{2}=820.126$ & $<0.001$ & $X^{2}{ }_{17}=829.382$ & $<0.001$ & & \\
\hline \multirow[t]{2}{*}{$5 / 6 / 2003$} & Order & $\mathrm{X}_{8}^{2}=218.165$ & $<0.001$ & $\mathrm{X}_{8}^{2}=272.608$ & $<0.001$ & $\mathrm{X}_{8}^{2}=496.973$ & $<0.001$ \\
\hline & Morpho-species & $\mathrm{X}_{18}^{2}=271.792$ & $<0.001$ & $\mathrm{X}^{2}{ }_{17}=97.794$ & $<0.001$ & $\mathrm{X}_{18}^{2}=512.341$ & $<0.001$ \\
\hline
\end{tabular}

Note: * Morpho-species classification is taxa within families that is morphologically distinct and are considered to be separate species. 
Table 5. Chi-square values comparing the proportion of prey items identified to morpho-species in the diets of three migrant birds species. Data collected during spring 2003 at Cibola NWR, Arizona.

\begin{tabular}{|c|c|c|c|c|c|c|}
\hline \multirow[t]{2}{*}{$\overline{\mathrm{DATE}}$} & \multicolumn{2}{|c|}{ Nashville Warbler vs. Orange-crowned warbler } & \multicolumn{4}{|c|}{ Nashville Warbler vs. Wilson's Warbler|Orange-crowned warbler vs. Wilson's Warbler } \\
\hline & $\mathrm{X}^{2}$ & $\mathrm{p}$ & $X^{2}$ & $\mathrm{p}$ & $\mathrm{X}^{2}$ & $\mathrm{p}$ \\
\hline $4 / 18 / 2003$ & $3 \mathrm{X}_{14}^{2}=77.50$ & $<0.00$ & & & & \\
\hline $5 / 6 / 2003$ & $X_{12}^{2}=58.67$ & $<0.00$ & $X_{14}^{2}=188.79$ & $<0.00$ & $X^{2}{ }_{12}=84.976$ & $<0.00$ \\
\hline
\end{tabular}

Note: Morpho-species classification is taxa within families that is morphologically distinct and are considered to be separate species. 
Table 6. Arthropods found in the diets of the three representative insectivores.

Sessions 4/18/2003 and 5/6/2003 data combined, all arthropods collected at Cibola NWR, Arizona.

\begin{tabular}{|c|c|c|c|c|c|c|c|c|c|c|}
\hline Taxa & Family (species) & $\begin{array}{l}\text { Morpho } \\
\text { Species }\end{array}$ & $\begin{array}{l}\text { Proportion } \\
\text { Nashville } \\
\text { Warbler } \\
(10)\end{array}$ & $\begin{array}{l}\text { in Diet } \\
\text { Orange- } \\
\text { crowned } \\
\text { Warbler } \\
(9)\end{array}$ & $\begin{array}{l}\text { Wilson's } \\
\text { Warbler } \\
(10)\end{array}$ & $\begin{array}{l}\text { Proportion } \\
\text { Available }\end{array}$ & $\begin{array}{l}\text { Tree } \\
\text { Species }\end{array}$ & $\begin{array}{l}\text { d Affiliati } \\
\text { Tree } \\
\text { species } \\
\text { Indicator } \\
\text { value }\end{array}$ & $\begin{array}{l}\text { Phenology } \\
\text { Zone }\end{array}$ & $\begin{array}{l}\text { Phenology } \\
\text { Indicator } \\
\text { value }\end{array}$ \\
\hline \multirow[t]{3}{*}{ Hemiptera } & Anthocoridae & & & & & & & & & \\
\hline & (Orius insidiosus) & Hem 7 & 48.5 & 23.0 & 6.4 & 8.4 & HM & $53.3^{*}$ & Flower & $47.0^{*}$ \\
\hline & Miridae & Hem13 & 0.3 & 0.0 & 0.0 & 4.7 & $\mathrm{HM}$ & $27.9 *$ & Flower & 18.2 \\
\hline \multirow[t]{3}{*}{ Homoptera } & Ciciidae & Hom 6 & 20.3 & 25.0 & 22.3 & 1.4 & $\mathrm{HM}$ & $42.6^{*}$ & Flower & $28.1^{*}$ \\
\hline & Psyillidae & Hom 8 & 10.7 & 5.0 & 5.3 & 8.4 & $\mathrm{HM}$ & $69.0 *$ & Flower/Leaf & $45.1^{*}$ \\
\hline & & Hom 9 & 4.8 & 21.0 & 0.0 & 12.4 & $\mathrm{HM}$ & $48.0^{*}$ & Flower/Leaf & $43.4^{*}$ \\
\hline \multirow[t]{2}{*}{ Thysanoptera } & Aelothripidae & Thy 1 & 0.0 & 1.0 & 0.0 & 6.5 & $\mathrm{HM}$ & $53.2 *$ & Flower & $58.4^{*}$ \\
\hline & Thripidae & Thy 2 & 3.8 & 5.0 & 3.2 & 34.5 & $\mathrm{HM}$ & $63.0 *$ & Flower & $73.4^{*}$ \\
\hline Neuroptera & Chrysopidae & Neu 1 & 0.0 & 1.0 & 1.1 & 0.4 & $\mathrm{HM}$ & $14.3 *$ & Flower & $26.5^{*}$ \\
\hline \multirow[t]{7}{*}{ Coleoptera } & Chrysomelidae & $\mathrm{Col} 2$ & 2.4 & 5.0 & 8.5 & 0.1 & $\mathrm{HM}$ & 5.90 & Flower/Leaf & 4.1 \\
\hline & & Col 3 & 0.3 & 0.0 & 0.0 & 0.7 & HM & $34.8^{*}$ & Flower & $32.4^{*}$ \\
\hline & Bruchidae & $\mathrm{Col} 4$ & 1.0 & 4.0 & 6.4 & 0.6 & $\mathrm{HM}$ & $13.7^{*}$ & Flower & 16.4 \\
\hline & Curculionidae & Col 5 & 1.0 & 2.0 & 2.1 & 0.7 & SM & $31.7^{*}$ & Leaf & 10.9 \\
\hline & Buprespidae & Col 7 & 0.0 & 0.0 & 2.1 & 0.1 & HM & 1.60 & Flower & 4.6 \\
\hline & Mordellidae & Col 16 & 3.8 & 0.0 & 0.0 & 0.6 & $\mathrm{HM}$ & $19.3^{*}$ & Flower & $19.1 *$ \\
\hline & Phalacridae & Col 17 & 0.3 & 0.0 & 0.0 & 0.3 & HM & 6.50 & Flower & 3.8 \\
\hline
\end{tabular}




\begin{tabular}{|c|c|c|c|c|c|c|c|c|c|c|}
\hline \multirow{3}{*}{ Diptera } & Anthicidae & Col 23 & 0.3 & 0.0 & 3.2 & 0.1 & SM & 2.50 & Flower/Leaf & 0.8 \\
\hline & Chloropidae & Dip 17 & 0.7 & 6.0 & 36.2 & 8.7 & $\mathrm{HM}$ & $84.5^{*}$ & Flower & $82.3 *$ \\
\hline & Asteiidae & Dip 18 & 0.0 & 2.0 & 2.1 & 11.2 & SM & $49.1 *$ & Leaf & $32.6^{*}$ \\
\hline Hymenoptera & Charapidae & Hym 30 & 1.0 & 0.0 & 0.0 & 0.1 & SM & 2.30 & Leaf & 8.6 \\
\hline
\end{tabular}

Tree species are honey mesquite (HM), and screwbean mesquite (SM). Indicator values derived from Monte Carlo tests with values ranging from 0 (no indication) to 100 (perfect indication). Asterisks denotes significance $<0.017$. Numbers in parenthesis are sample sizes. 


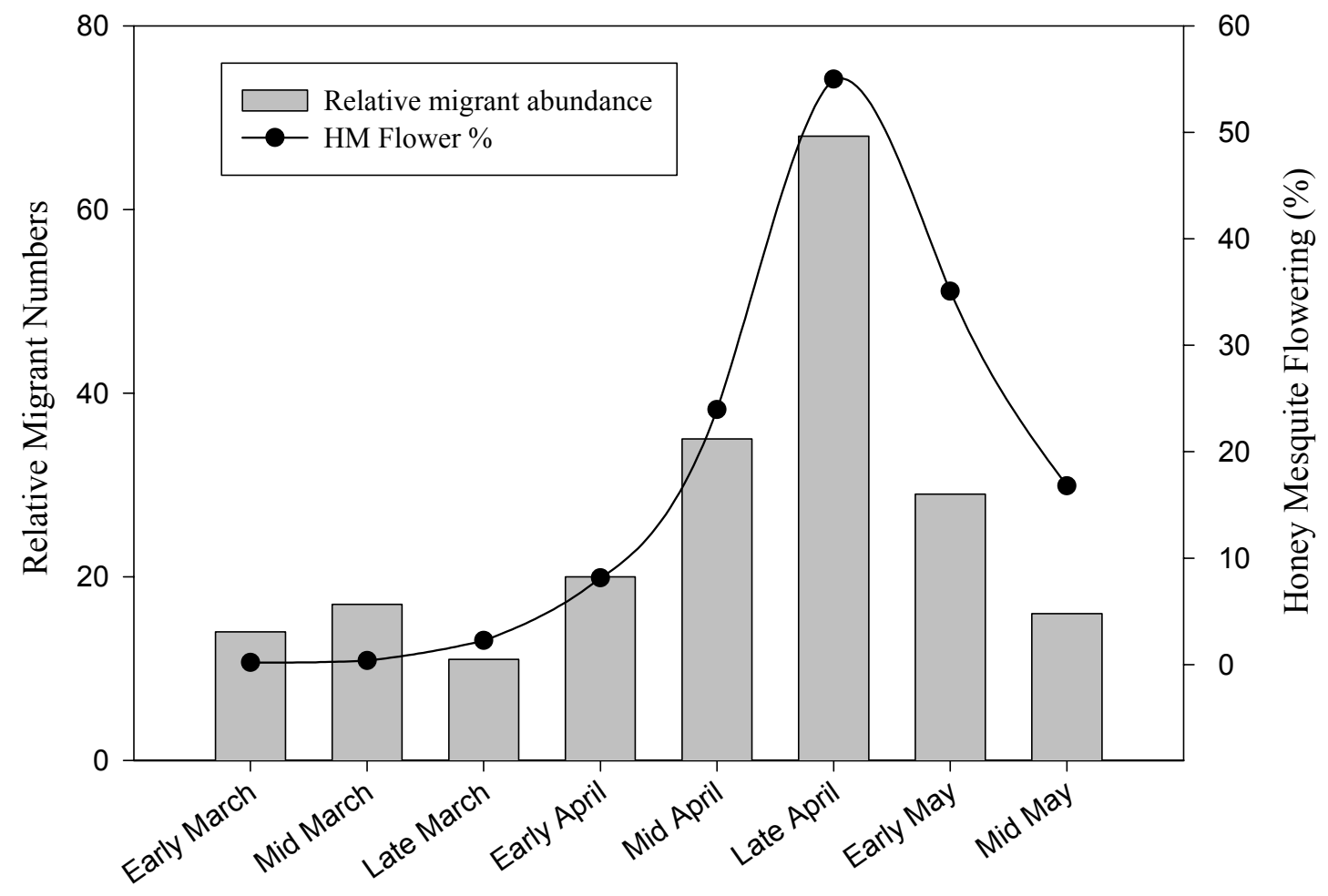

Fig. 1. Relative insectivorous migrant abundance during honey mesquite flowering throughout Spring migration at Cibola NWR in Arizona. Dates and migrant numbers pooled for 2002 and 2003. Pearson's Correlation: $\mathrm{R}=0.76, \mathrm{p}=0.03$. 

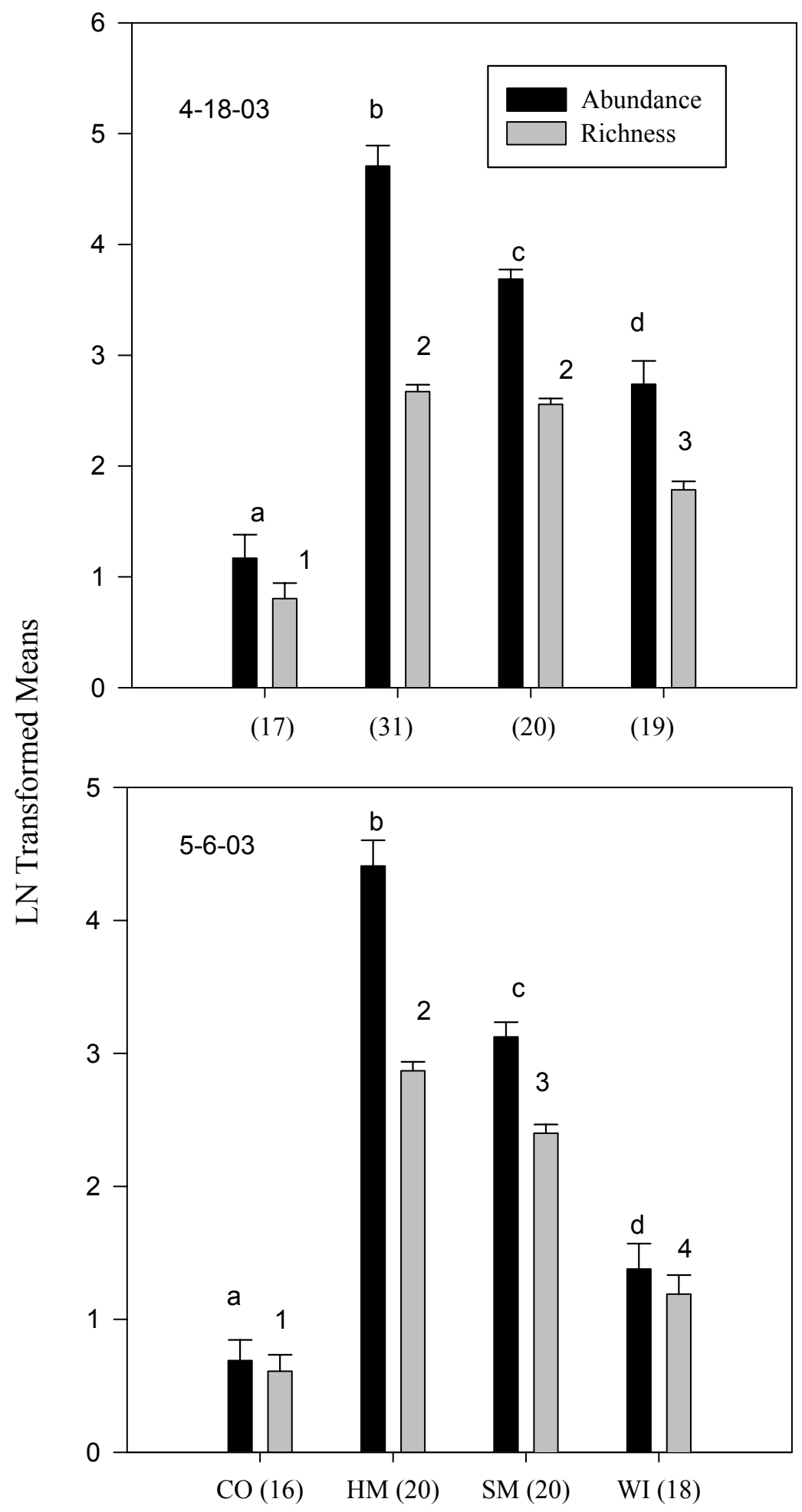

Fig. 2. Arthropod sampling from Fremont Cottonwood (CO), Honey mesquite (HM), Screwbean mesquite (SM) and Goodding's willow (WI) in 2003 at Cibola NWR in Arizon: A sample unit is a branch from a tree. Number in parenthesis are sample sizes. Letters compare abundance, numbers compare richness. Numbers and letters are not related. 


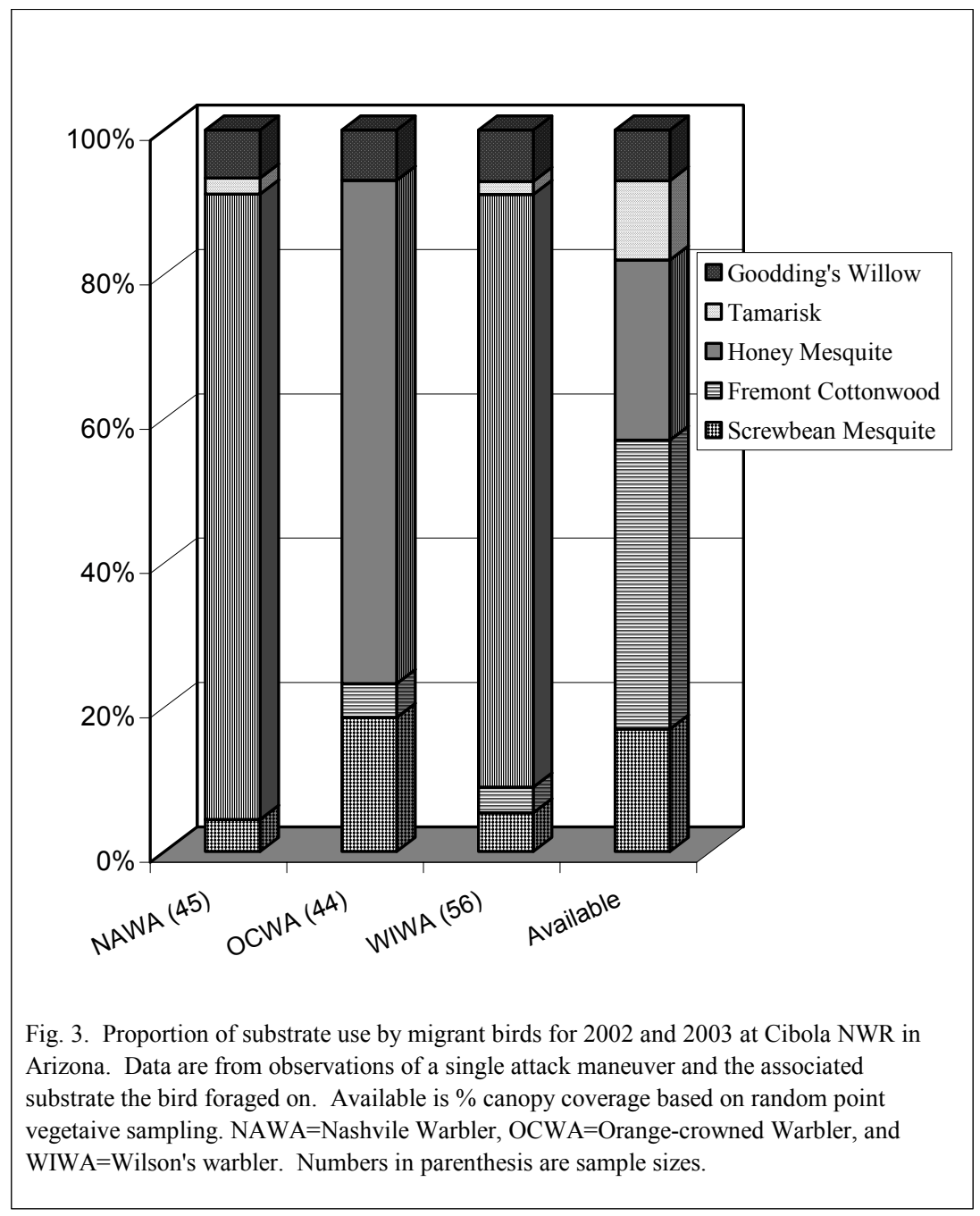



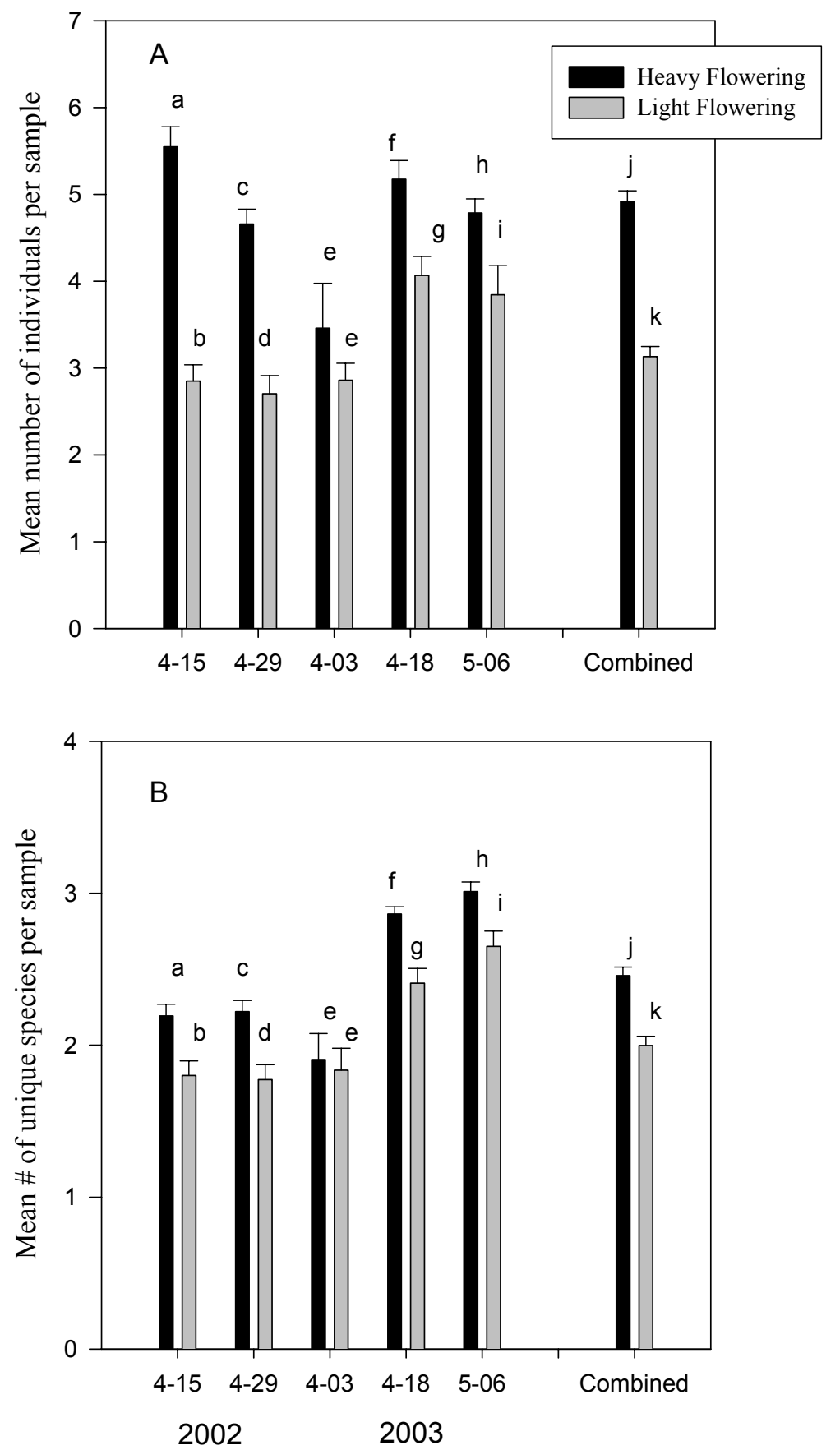

Fig. 4. Panel (A) flowering affects arthropod abundance. Panel (B) flowering affects arthropod richness. Branch samples from Honey mesquite trees in heavy and light levels of flowering ( $\mathrm{n}=20$ samples in each 2002. In 2003; 4-03-03 had 13 light and 7 heavy samples, 4-18-03 had 13 light and 18 heavy sampels, and 5-06-03 had 8 light and 12 heavy samples $+1 \mathrm{SE}$ are shown). Arthropods were collected at Cibola NWR in Arzona, spring 2002 and 2003. 


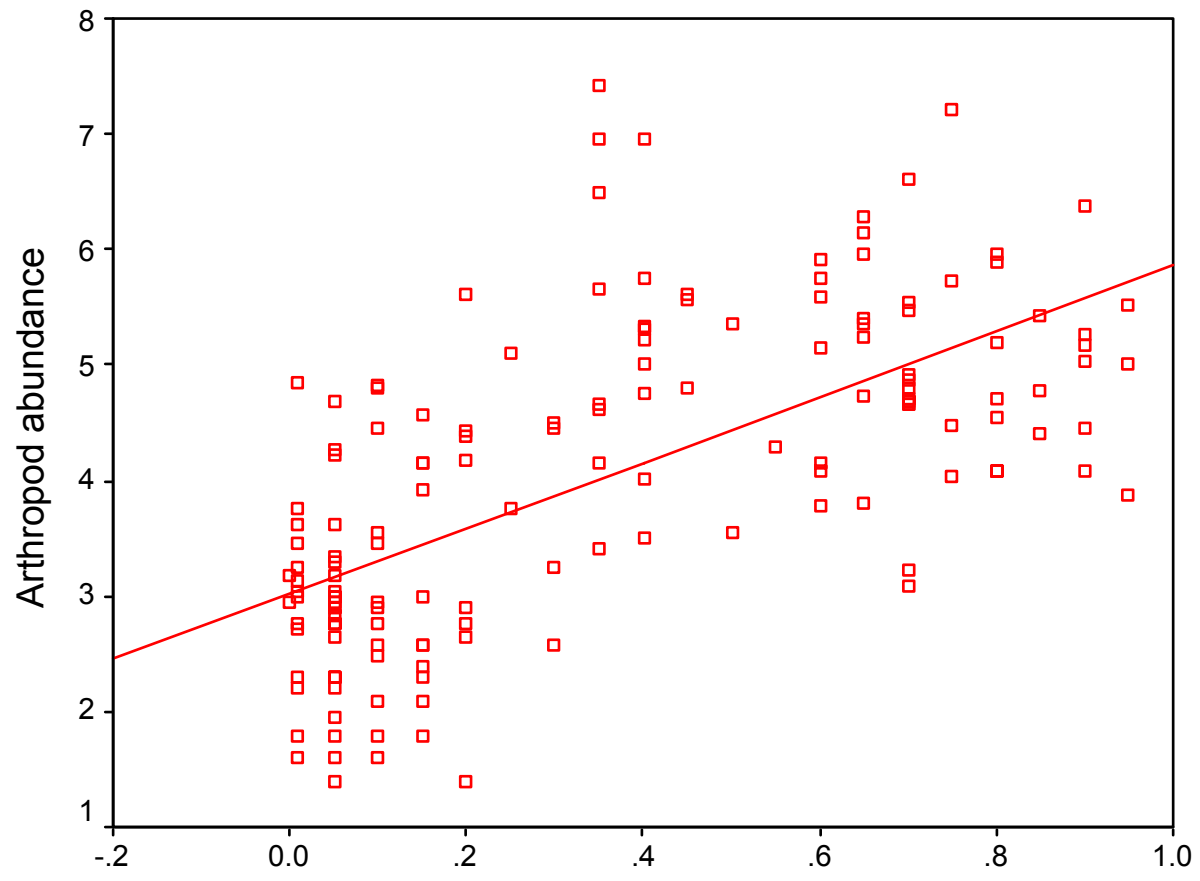

Flower Index

Figure 5. Arthropod abundance increases as flowering level increases.

$\mathrm{r}^{2}=0.409, \mathrm{p}=0.00$. Arthropod data is from 2002 and 2003 at Cibola NWR in Arizona. A sample unit is the arthropods collected from a honey mesquite branch. Arthropod abundance is LN transformed. 


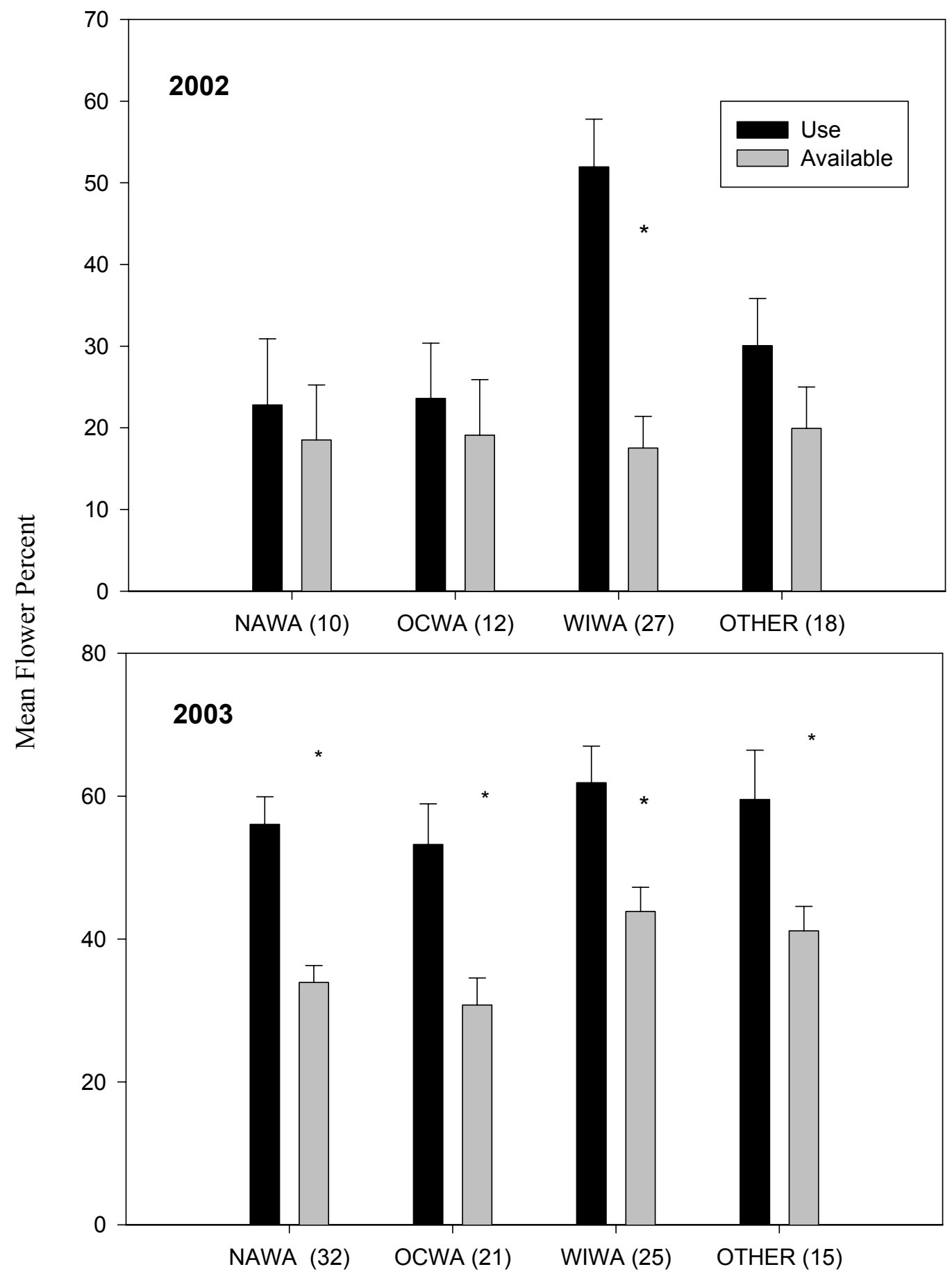

Fig. 6. 2002 and 2003 mean flower levels (honey Mesquite) used by migrants compared with mean flower availability at the site. OTHER = BTYW, HEWA, LUWA, MGWA, TOWA, WAVI pooled for each year. Wilcoxon Signed Ranks Tests, * indicates significance at the 0.05 level. Diferences in availability are due to changing phenology conditions through spring. Data from Cibola NWR, Arizona. 


\section{Three Warblers}

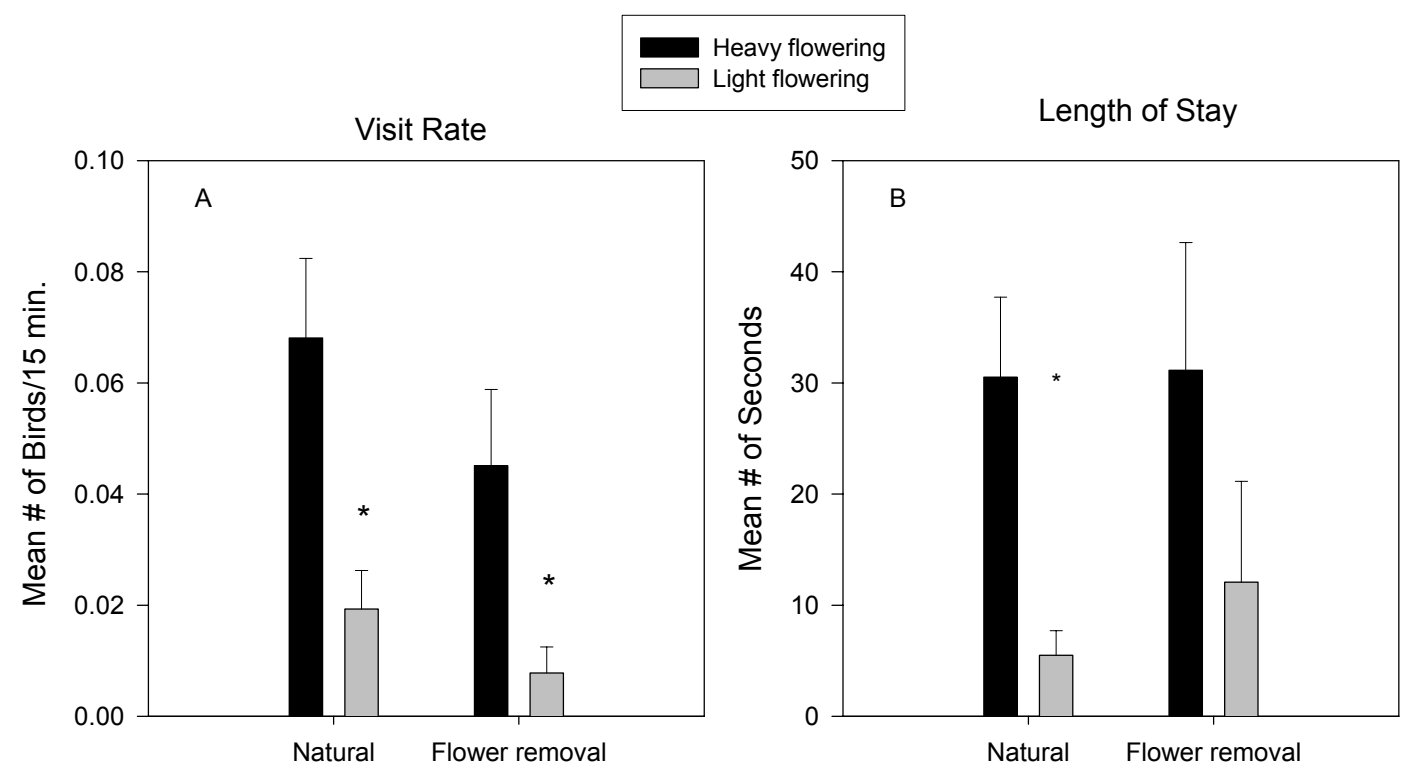

Attack Ratio

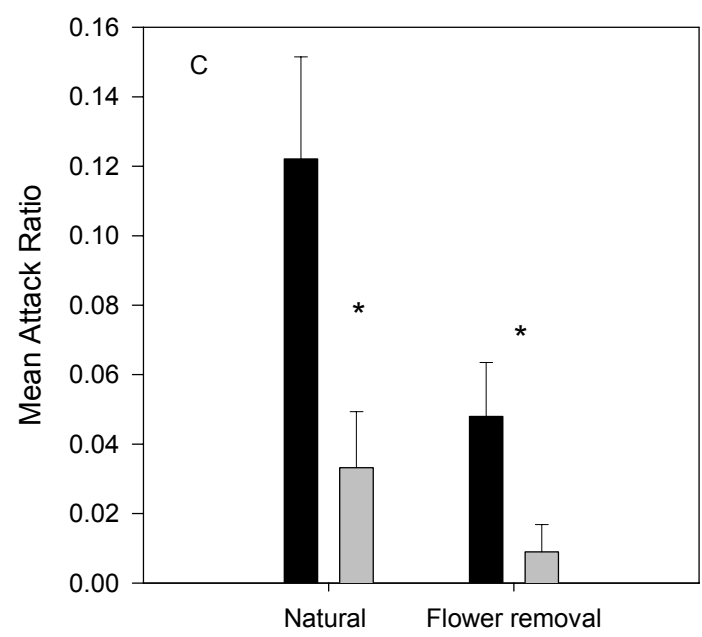

Fig. 7. Natural Pairs are simultaneous tree observations of birds at heavy and light flowering levels $(n=49$ pairs).

Flower removal pairs are simultaneous tree observations of birds at control (heavy) and de-flowered pairs ( $n=34$ pairs). Three warblers = NAWA, OCWA, and WIWA were pooled for 2002 and 2003. Data collected at Cibola NWR, Arizona.

A) Visit rate is the mean number of birds visiting a tree within the pair during the 15 minute observation period. B) Length of Stay is the mean number of seconds birds foraged at a tree within the pair during the 15 minute observation period. C) Attack Ratio is the number of seconds birds were in attack maneuvers

(glean, eat, hammer, probe) divided by the number of seconds in a given observation bout during the 15 minute observation period. Wilcoxon Signed Ranks test, * indicates significance at the 0.05 level. 


\section{Other Birds}
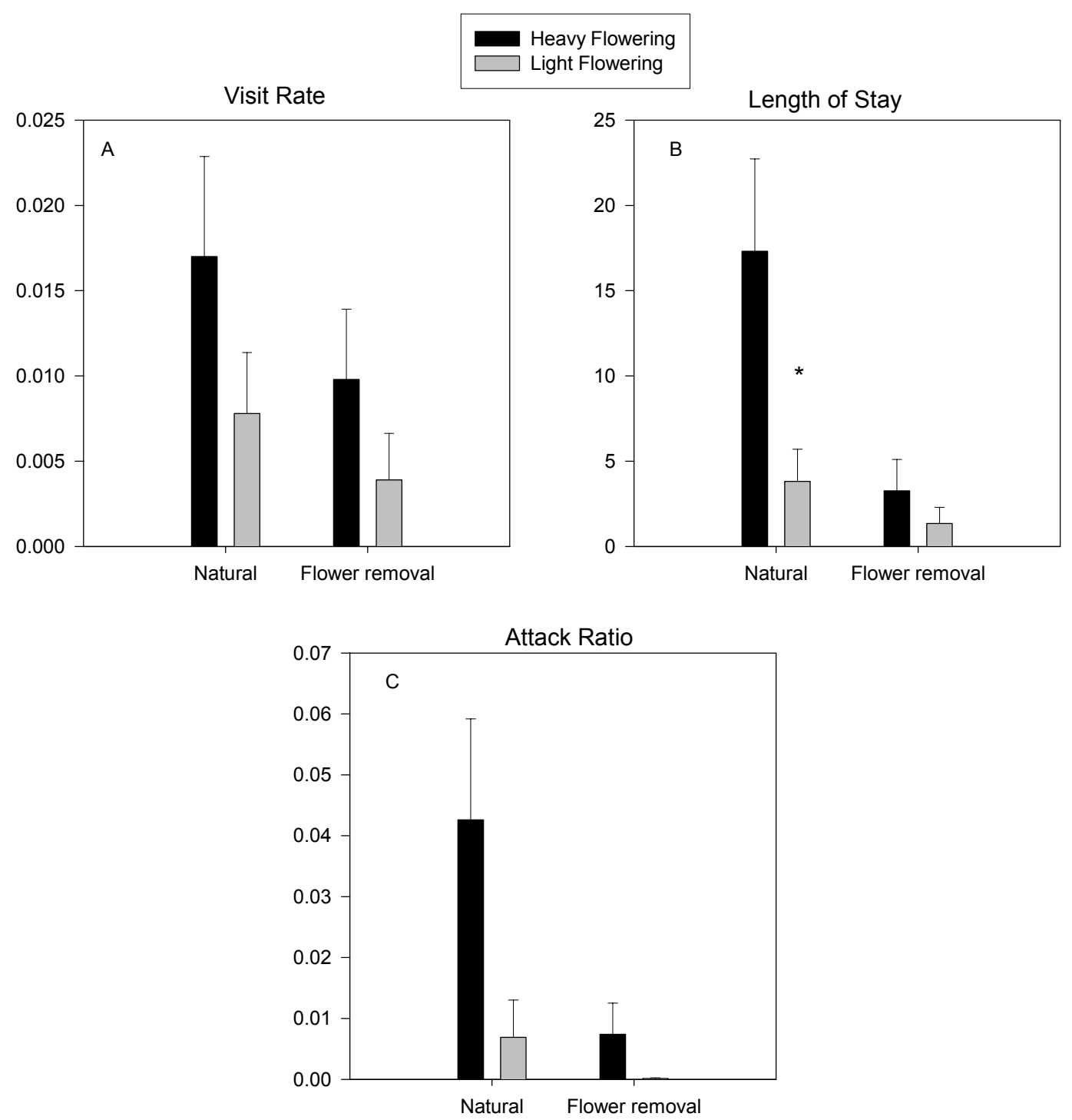

Fig. 8. Natural Pairs are simultaneous tree observations of birds at heavy and light flowering levels $(n=49$ pairs). Flower removal pairs are simultaneous tree observations of birds at control (heavy) and de-flowered pairs ( $n=34$ pairs). Other birds are BTYW, LABU, LUWA, MGWA, PLVI, RCKI, WAVI, YBCH, and YEWA and were pooled for 2002 and 2003. Data collected at Cibola NWR, Arizona. A) Visit rate is the mean number of birds visiting a tree within the pair during the 15 minute observation period.

B) Length of Stay is the mean number of seconds birds foraged at a tree within the pair during the 15 minute observation period. C) Attack Ratio is the number of seconds birds were in attack maneuvers

(glean, eat, hammer, probe) divided by the number of seconds in a given observation bout during the 15 minute observation period. Wilcoxon Signed Ranks test, * indicates significance at the 0.05 level. 

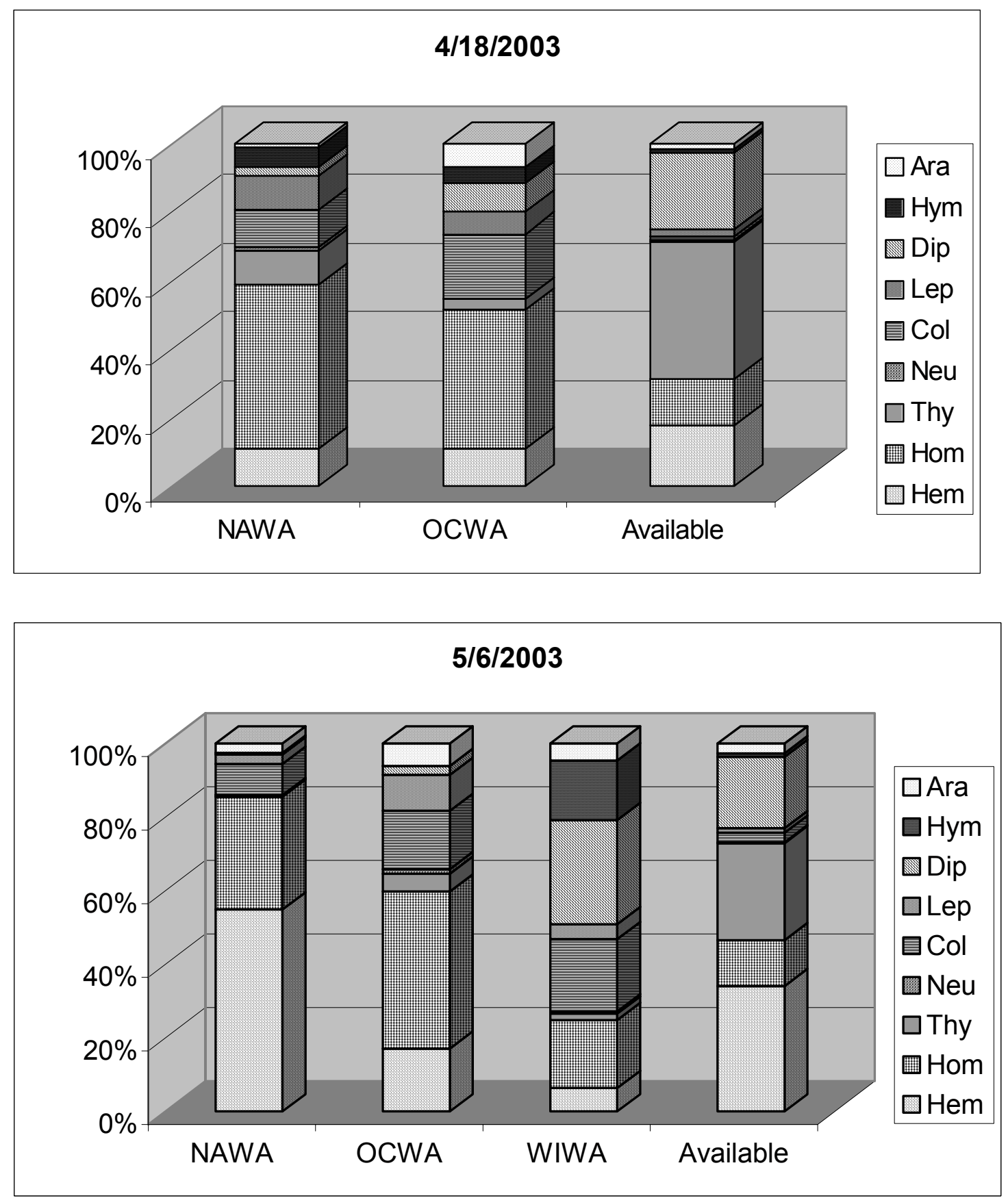

Figure 9. Proportion of items identified to order found in the diets of the three representative insectivores (Nashville, Orange-crowned, and Wilson's warblers).

Orders are Hemiptera (true bugs), Homoptera (leaf hoppers), Thysanoptera (thrips), Neuroptera (Antlions), Coleoptera (beetles), Lepidoptera (butterfly larvae), Diptera (flys), Hymenoptera (wasps and bees), and Araneae (spiders). Two sampling periods are presented in 2003 from Cibola NWR, Arizona. 

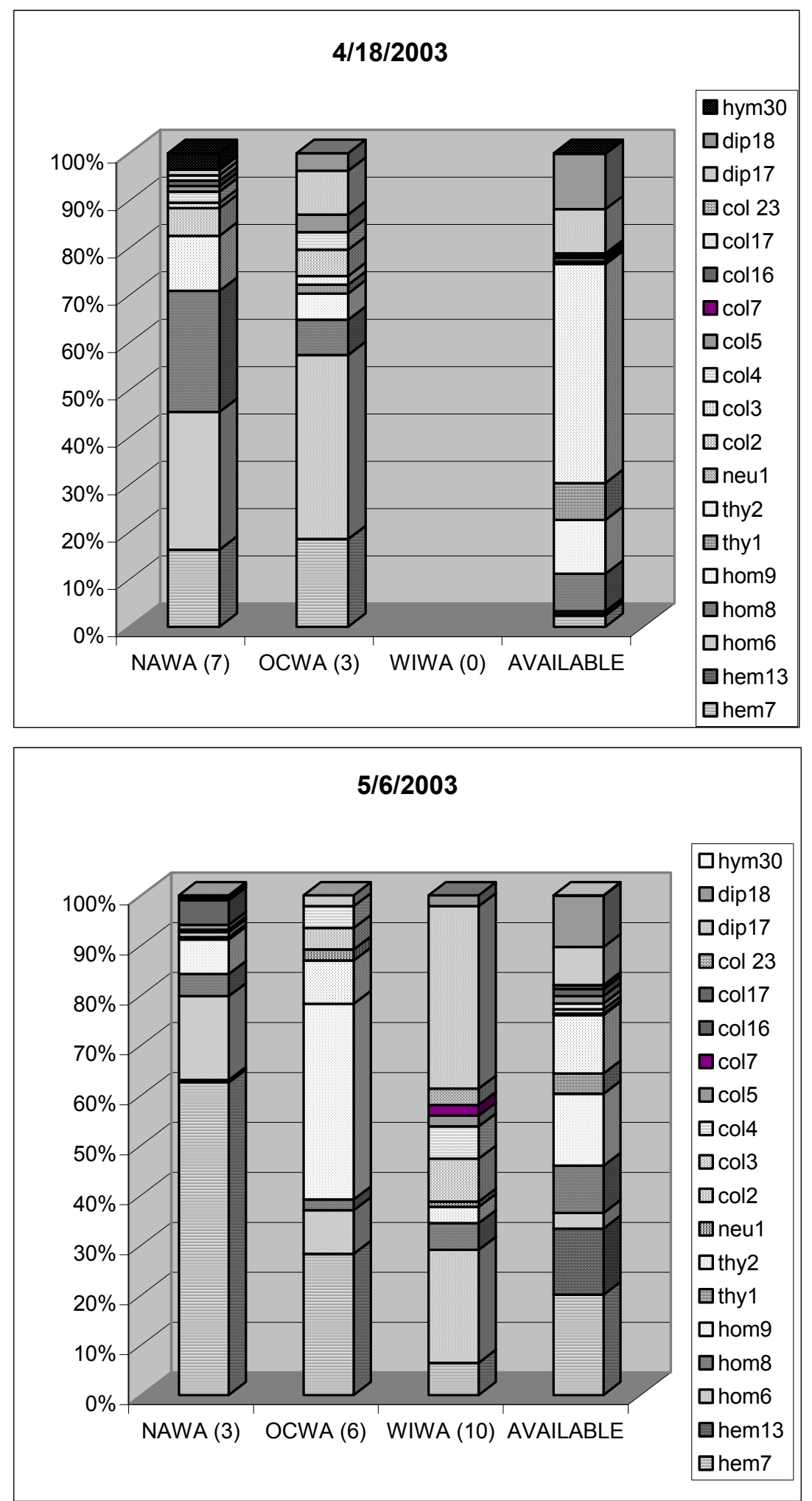

Figure 10. Proportion of items identified to morpho-species (morphologically distinct taxa) found in the diets of the representative insectivores (Nashville, Orange-crowned, and Wilson's Warblers).

Two sampling periods are presented in 2003 from Cibola NWR, Arizona. 

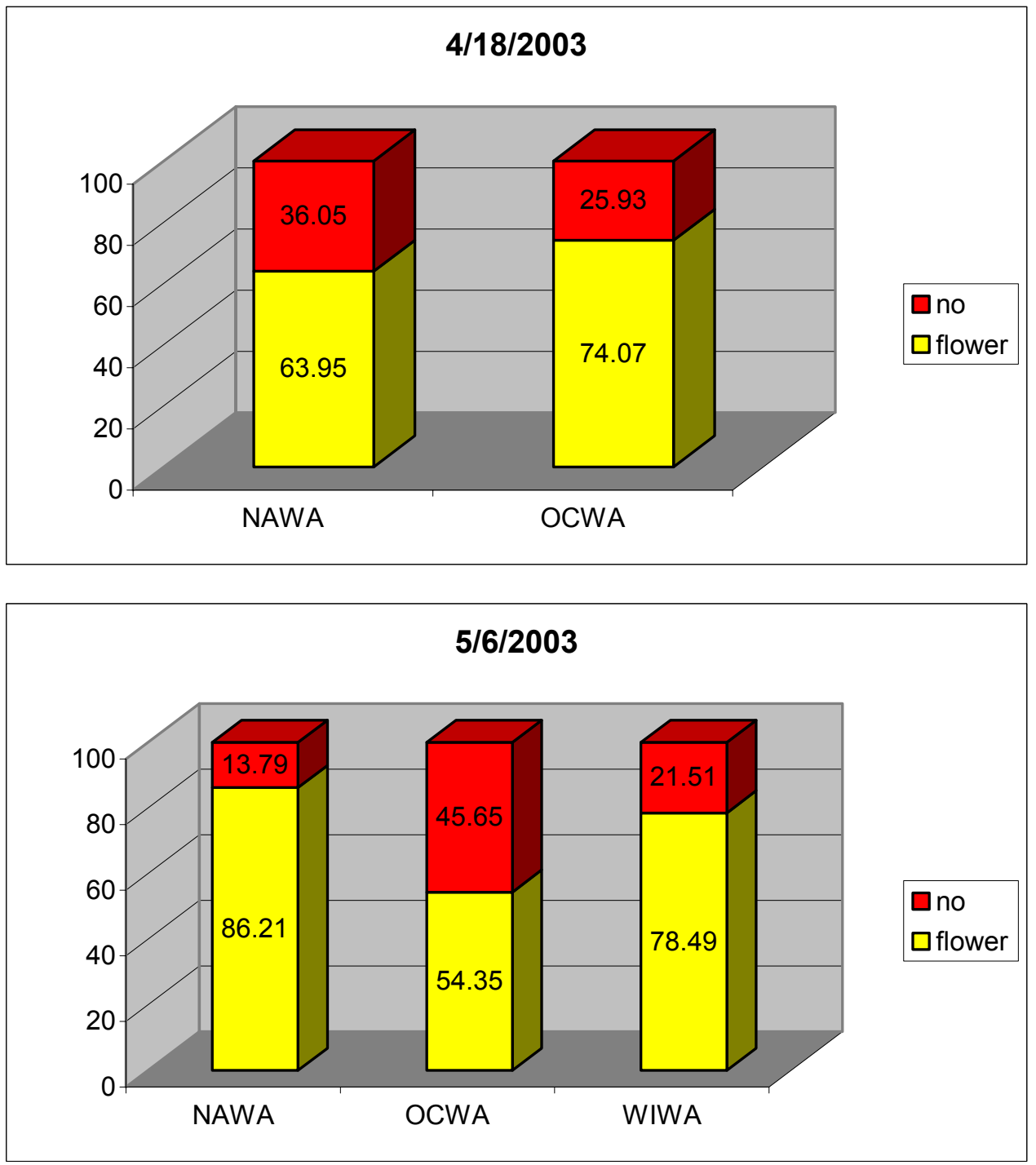

Figure 11. Proportion of insects significantly affiliated with the flowering condition found in the diets of the three representative insectivores (Nashville, Orange-crowned, and Wilson's Warblers).

Significant indicator values for taxa were derived from Monte Carlo tests. Two sampling periods are presented in 2003 from Cibola NWR, Arizona. 